\title{
Microalgae Harvesting and Processing: A Literature Review
}

\section{A Subcontract Report}

\author{
G. Shelef \\ A. Sukenik \\ M. Green
}

August 1984

Technion Research and Development Foundation Ltd.

Haifa, Israel

Prepared under Subcontract No. XK-3-03031-01

SERI Technical Monitor: Robins P. McIntosh

Solar Energy Research Institute

A Division of Midwest Research Institute

1617 Cole Boulevard

Golden, Colorado 80401

Prepared for the

U.S. Department of Energy

Contract No. DE-AC02-83CH10093 
Printed in the United States of America Available from:

National Technical Information Service

U.S. Department of Commerce

5285 Port Royal Road

Springfield, VA 22161

Price:

Microfiche A01

Printed Copy A04

\section{NOTICE}

This report was prepared as an account of work sponsored by the United States Government. Neither the United States nor the United States Department of Energy, nor any of their employees, nor any of their contractors, subcontractors, or their employees, makes any warranty, express or implied, or assumes any legal liability or responsibility for the accuracy, completeness or usefulness of any information, apparatus, product or process disclosed, or represents that its use would not infringe privately owned rights. 


\section{FOREWORD}

This report is a literature review on microalgal harvesting and processing submitted as partial fulfillment of subcontract XK-3-03031-01. The work was performed under subcontract to SERI with funds provided by the Biomass Energy Technology Division of the U.S. Department of Energy.

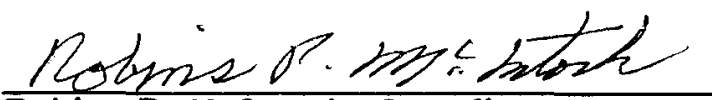

Robins P. McIntosh, Coordinator

Aquatic Species Program

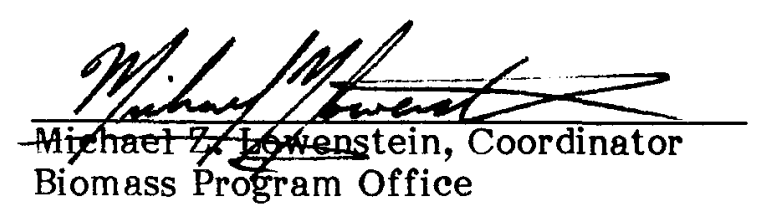

Atanlay Ybum

Stanley R. Bull, Director

Solar Fuels Research Division 


\section{SUMMARY}

\section{Objective}

The objective of this report is to present a discussion of the literature review performed on methods of harvesting microalgae.

\section{$\underline{\text { Diseussion }}$}

There is no single best method of harvesting microalgae. The choice of preferable harvesting technology depends on algae species, growth medium, algae production, end product, and production cost benefit.

Algae size is an important factor since low-cost filtration procedures are presently applicable only for harvesting fairly large microalgae. Small microalgae should be flocculated into larger bodies that can be harvested by one of the methods mentioned above. However, the cells' mobility affects the flocculation process, and addition of nonresidual oxidants to stop the mobility should be considered to aid flocculation.

The decision between sedimentation or flotation methods depends on the density difference between the algae cell and the growth medium. For oil-laden algae with low cell density, flotation technologies should be considered. Moreover, oxygen release from algae cells and oxygen supersaturation conditions in growth medium support the use of flotation methods.

If high-quality algae are to be produced for human consumption, continuous harvesting by solid ejecting or nozzle-type disc centrifuges is recommended. These centrifuges can easily be cleaned and sterilized. They are suitable for all types of microalgae, but their high operating costs should be compared with the benefits from their use.

Another basic criterion for selecting the suitable harvesting procedure is the final algae paste concentration required for the next process. Solids requirements up to $30 \%$ can be attained by established dewatering processes. For more concentrated solids, drying methods are required.

The various systems for algae drying differ both in the extent of capital investment and the energy requirements. Selection of the drying method depends on the scale of operation and the use for which the dried product is intended.

\section{Canclusions}

The literature review on microalgae harvesting technologies does not reveal any revolutionary conceptual advances since the first comprehensive study done by Golueke and Oswald (1965). Nevertheless, optimizing various trains of processes can not only reduce the cost, but can render the whole scheme economically feasible. The existing literature is not conclusive enough to propose such optimal train of harvesting processes, and the continued work of the Technion Group on this project will try to establish these optimal processes. 


\section{TABLE OF CONTENTS}

Page

1. Introduction $\quad 1$

2. The stability of microalgae with respect to their separability from aqueous suspensions. $\quad 4$

$2.1 \quad$ Colloidal character of microalgae suspension 4

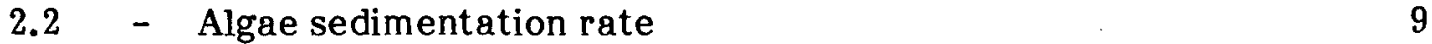

3. Flocculation of microalgae 11

4. Algae harvesting technologies $\quad 16$

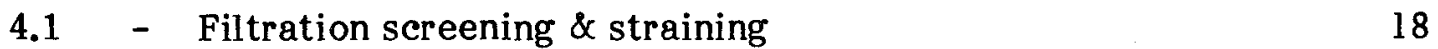

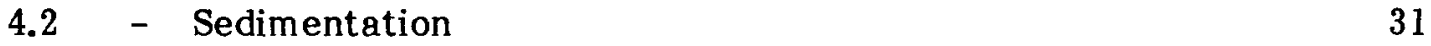

4.3 - Flotation 34

4.4 - Centrifugation 40

$\begin{array}{ll}\text { 5. Algal drying } & 49\end{array}$

6. Summary and conclusion $\quad 56$ 
1. InTROUCW10

liass culture of microalgae can be practiced to attain difterent cbjectives such as: production of hydrocarbons, proteins, various organic substances, wastewater treatment, solar energy conversion or coribination of the above.

An algal mass culture is attainable in outdoor ponds under suitable climatic conditions. High rate algal pond (HRAP) is an open photosynthetic reactor which is operated for mass algal culture and intended to maximize algal production per unit of area. It consists therefore of a shallow race-way or meancering channel pond where mixing is provided to keep the algue in suspension.

The operational knowhow and the scientific background of microalgae production in HhaP are well based on long experience. The scientific foundamentals, the operational strategies and the various uses of the HRAP are beyond the scope of this review, and the data on that topics is available in the literature (shelef et al., 1980, Azov et al., 1982, Oswald 1974, Soeder, 1980).

The product of the HRHF is an effluent of algal culture which contains up to $600 \mathrm{mg} / 1(0.06 \%)$ microalgae. As in other microorganism procuction systems the separation of the suspended cells from the culture medium is an essential and important step. The efficient separation dewatering and dryirig of inicroalgae is probably the nost essential factor in the economic feasibility of any lifcroalzae production systen.

In combined system of HAH for wastewater treatment, water renovation and protein production, the algal separation has a dual purpose: a) renovation of algal free treated water and b) concentration of protein rich algal biomass available for animal feed. In 'clean' systems that their media are consisted of a mixture of 
defined salts which are dissolved in water, the algal separation and concentration is essential for the further processing steps according to the desired end product. The resultant algal free culture medicin may be recycled, after nutrients addition, into the ufap.

Microdigae by their stilall size $(5-50 \mu \mathrm{m})$, their negativeiy

charged surfaces and in some cases their mobility, form stable suspensions and hereby difficulties in their separation anc recovery (Tenry et al., 1968). Techrological solutions for separation of algae fron that stable suspensions should be given in the processing sequence of microalgae production (Fig. 1.1).

The term algae harvesting refors to the concentration of fairly diluted (ca. $0.0 c-0.06$ TSS) algae suspension until a slurry or paste containine 5-25\% TSS and rore is obtained. As it is indicated in

Fig. 1.1, such concentrated slurry is attainable by one step harvesting process or by two step process consisting of harvesting step which brings the algal slurry to 2-7\% TSS, and dewatering step whose end product is an algal paste of $15-25 \%$ TSS. The concentration of the resultant aigal paste or slurry greatly influences the subsequential processing steps as drying or organic substances extraction (Nohn $1978 \& 1980$ ).

The methods and devices which are suitable for microalgae separation from HRAP effluent depend on the algae species, the production system and the objectives of the final product. (liohn 1980, Dodo, 1980). This review deals with separation and processing methods of microalgae from the pond effluent. The stability of tiicroalgae suspensions, and the principles which riay be used to 


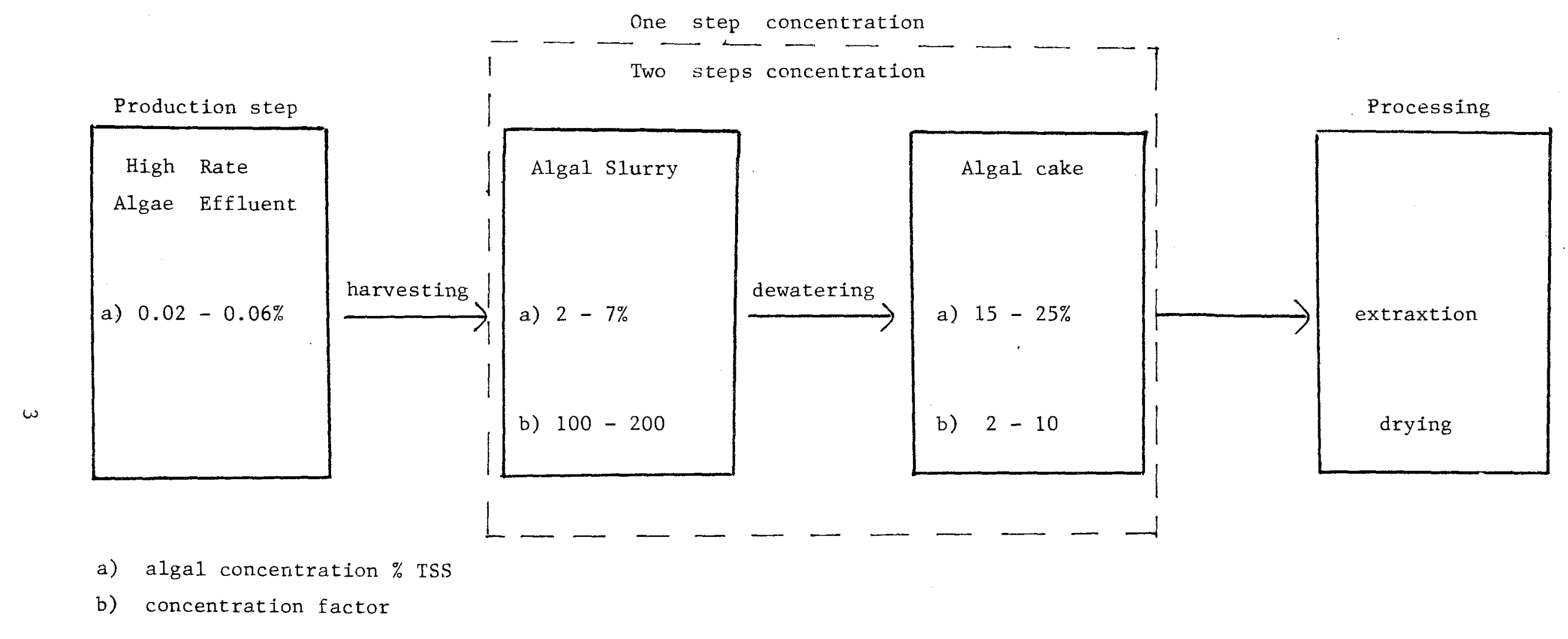

Fig. 1.1 -Schematic presentation of algal production and processing. 
overcome it during the separation step, are discussed. Updated technologies for algae and other microorganisms separation and processing are, critically reviewed. Promissing technologies are recommended for further improvement and application for oil laden microalgae separation.

\author{
2. THE STABILITY OF MICROALGAE WITH RESPECT TO THEIR SEPARABILITY \\ FROM AQUEOUS SUSPENSIONS
}

The HRAP effluent consists of a culture medium containing microalgae biomass which form stable suspension. There are two factors which affect the stability of that suspension: a) algal surface electric charge which causes the development of intercellular repulsion forces. b) tiny cell dimensions and cell density close to that of the medium cause slow cell sinking rate.

2.1 The colloidal character of an algal suspension. Both the electric repulsion interactions between algal cells and cell interactions with the surrounding water contribute to the stability of the algal suspension (Tenny et al., 1968). Most of the planktonic algate are characterized as negatively charged surfaces. The intensity of that charge is a function of algal species, ionic strength of medium, pil and other environmental conditions (Ives 1959 \& Hegewald 1972). The sources of the algal surface electric charge are: ionization of ionogenic functional groups at the algal cell wall (Golueke \& Oswald 1970) and selective adsorption of ions from the cliture medium (Shaw 1969). 
The electric state of a surface depenas on the spatial distribution of free charges (ions) in its neighborhood (Stumm \& Morgan 1981) and is idealized as an electrochemical double layer. Cne layer is described as a fixed charge attached to a particle surface and is called the Stern layer. The other is called Gouy layer or diffuse layer which contains an excess of counter ions (ions of opposite sign to the fixed charge) and a deficit of co-ions (of the same sign as the fixed charge). The distribution of ions and potential at solid solution interface is described in Figure 2.1.1.

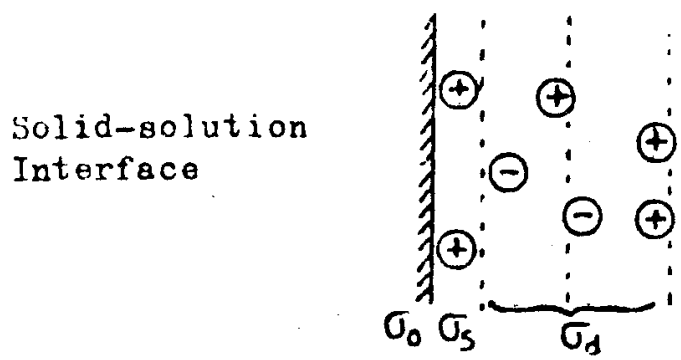

Potential
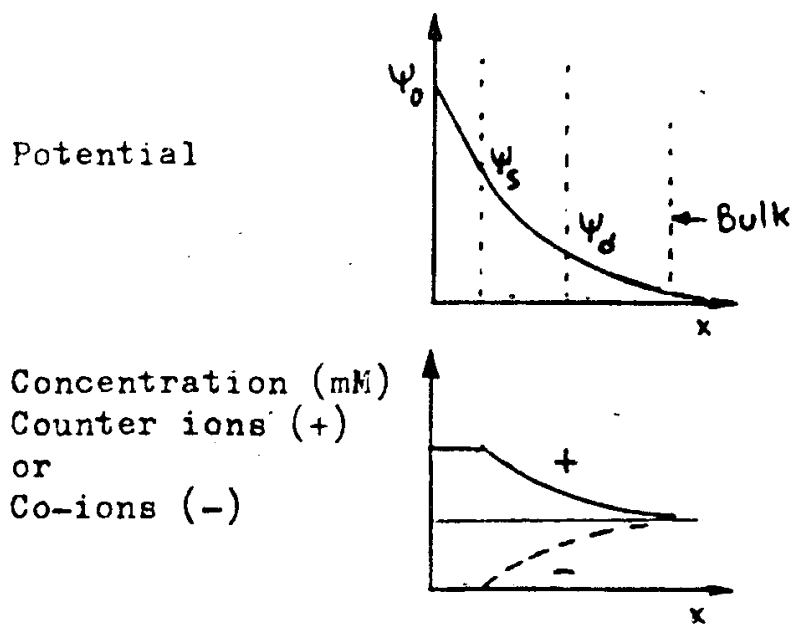

Fig. 2.1.1 - The distribution of ions and potential at solid solution interface. 
Heither the potential at the surface $\left(\psi_{0}\right)$ nor the Stern potential $\left(\psi_{S}\right)$, nor the potential at the border of Stern and diffuse layer $(\psi d$ ) can be directly measured. Instead, the zetid potential $\zeta$ - the potential measured at the shear plane (that seperates the solid surface and the mobile liquid), is the one generally used and is obtained by simple electrokinetic methods. The zeta potencial is assumed to be equal to $\psi_{\mathrm{d}}$ although it is. not necessarily correct.

A simplified formulation (valid for small potentials) shows the potential decreases exponentially with the distance

$$
\psi=\psi d \exp (-K \cdot X)
$$

where $\psi$ is the potential at a distance $X$ and $K$ is the reciprocal of the double layer thickness and is defined by equation

$$
k=\left(\frac{8 \cdot \pi \cdot e \cdot n_{o} \cdot z^{2}}{6 \cdot k \cdot T}\right)^{\frac{1}{2}}
$$

where $Z$ is the charge or counter ion whose concentration is $n_{0}$. $k$ is bolzman constant, $T$ Kelvin temperature and $e$ is a basic charge.

The above equations show that the electric potential at a given distance in the diffused layer is affected by the valency of the counter ion and its concentration. Compression of the electric double layer is attainable either by increasing the counter ion concentration or by using counter ions of higher 
valency.

The interaction between colloidal particles are affected by the electric repulsion forces on one hand and attraction forces of Van-der-Waals on the other hand. The combined effect of those two energies is shown in Figure 2.1.2. There is a potential barrier to be overcome if attachment is to be attained. It can be exceeded by the kinetic energy of the particles or alternatively by the reduction of the energetic barried. This is done by compressing the double layer (increasing $K$ ) through addition of electrolytes to the solution or ions of higher valences.

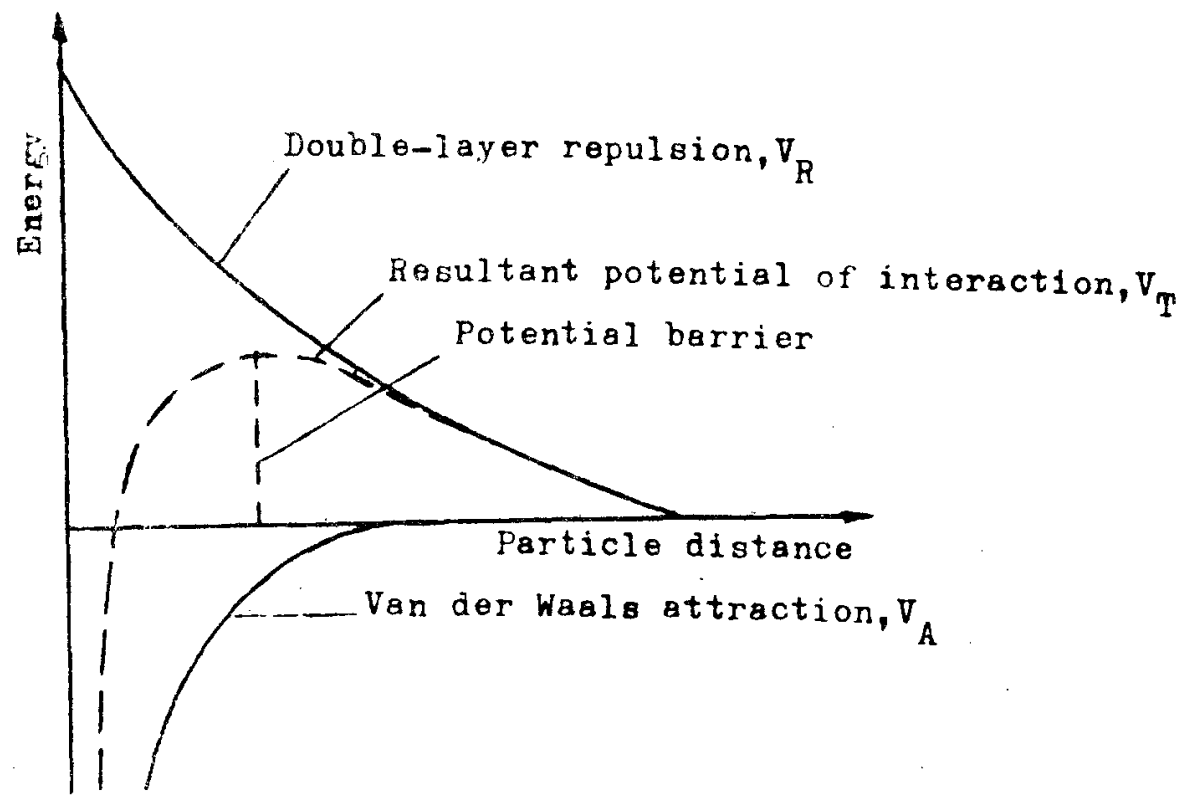

Fig. 2.1.2 - Combined effect of electric repulsion and Van-der-waals attraction energy (Ref. Stumm \& Morgan 1981). 
Although the double layer theory is of great theoretical importance, its use is restricted to cases where specific chemical interactions do not play a role in colloid stability (0Melia 1978). Destabilization of colloidal suspension as a result of specific chemical interaction is attainable by the presence of polyelectrolytes or polyhydroxy complexes.

Hydrolysis of metal ions (for example $\mathrm{Fe}\left(\mathrm{H}_{2} \mathrm{O}_{6}^{3+}\right.$ and $\mathrm{Al}\left(\mathrm{H}_{2} \mathrm{O}\right)_{6}^{3+}$ ) is described as a stepwise consecutive replacement of $\mathrm{H}_{2} \mathrm{O}$ molecules in the hydration shell by $\mathrm{CH}^{-}$ions (Stumm \& OMelia, 1968), according to the scheme shown in Fig. 2.1.3. The effects of ferric and aluminium salts are brought about by their hydrolysis products and not try the simple aqua-metal ion themselves. Over dose of the hydroxo complexes can restabilize dispersions by a reversal of the charge of the colloidal particles

$$
\begin{aligned}
& {\left[\mathrm{Al}\left(\mathrm{H}_{2} \mathrm{O}_{6}\right]^{+++} \underset{\mathrm{OH}^{-}}{\stackrel{\mathrm{OH}^{-}}{-}}\left[\mathrm{Al}\left(\mathrm{H}_{2} \mathrm{O}\right)_{5}(\mathrm{OH})\right]_{\mathrm{OH}^{-}}^{++} \stackrel{\mathrm{OH}^{-}}{\longrightarrow}\left[\mathrm{Al}^{-}\left(\mathrm{H}_{2}{ }^{\mathrm{O}}\right)_{4}(\mathrm{OH})_{2}\right]^{+}\right.} \\
& \begin{array}{c}
{\left[\mathrm{Al}_{6}(\mathrm{OH})_{15}\right]_{(\mathrm{aq})}^{+++} \text {or }\left[\mathrm{Al}_{8}(\mathrm{OH})_{2 \mathrm{O}}\right]_{(\mathrm{aq})}^{++++} \stackrel{\mathrm{OH}^{-}}{\longrightarrow} \mathrm{Al}(\mathrm{OH})_{3}\left(\mathrm{H}_{2} \mathrm{O}\right)_{3}(\mathrm{~B}) \stackrel{\mathrm{OH}^{-}}{\longrightarrow}} \\
{\left[\mathrm{Al}(\mathrm{OH})_{4}\right]^{-}}
\end{array}
\end{aligned}
$$

Fig. 2.1.3 - Stepwise conversion of a positive aluminiuli ion into negative one (Kef: Stumm and O'Melia 1968). 
Organic polymers, usually those of quite high molecular weight are considered as good flocculants. The polymeric flocculation is explained by bridging model says that a polymer can attach itself to the surface of a colloidal particle by several segments being remainder segments extended into solutions. These segments are then able to attach on vacant sites on other particle forming a three dimensional floc network (Gregory 1979).

Destabilization and flocculation of algal suspension is an important procedure in most of the various algal separation process and is described separately in a following section.

\subsection{Sinking rate of microalgae.}

Planktonic algal cell can be considered as a body which falls in aqueous medium and is affected by the gravity force on one hand, and drag forces on the other. Within a short time this body exceeds constant sinking velocity which is described by Stokes law (eq. 2.2.1)

$$
v=\frac{g \cdot d^{2}\left(\rho^{1}-\rho\right)}{18 \eta}
$$


where $V$ is the falling velocity, 8 - gravity force, $d$ - particle diameter, $\rho$ and $p^{1}$ the density of the medium and the particle, respectively, and $r_{1}$ is the medium viscosity.

According to Eq. 2.2.1, the falling velocity of a body. decreases either by increasing medium viscosity or reducing the ceil-medium density difference or by decreasing cell diameter. Stokes lat is afplicable for spherical bodies and any diversity from sphericity reduces the sinking rate, inversely, to the coefficient of form resistent $\phi$

$$
V=\frac{y^{2} d^{2} \cdot\left(\rho^{2}-\rho\right)}{\left.(8 \cdot i)^{\circ} \phi\right)}
$$

while $\phi$ is a dinensionless parameter and calculated from the ratio of the sinking rate of sphere of the same diameter and that of the actual body.

The sinking velocity of planktonic algae in ratural habitat is disturbed by cell mobility, water turbulence and upwelling caused by winds and temperature stratification (Hutchinson, 1967). Plonktonic algae in ecosystem reduce their sinking rate by the following methods: a) motility, b) reducing cell dimensions, c) increament of the drag forces as in Scenedesmus species which contain seta (Conway \& Trainer 1973), d) reducing cell density as in many blue green al gae which contain gas vacuoles (Fogg 1975, Pearl \& Ustach 1982).

Imreasing of algal celz. sedimentation rate can be obtained by increasing cell dimensions, i.e., by cells aggregation into 
large body. This principle is applied in algal separation processes where chemical flocculants are added and cause large algal flocs which settle rapidly to the container bottom. Alternatively, tiny air bubbles which may adsorbe to the already formed algal flocs will reduce dramatically the floc density and cause the floc to float. Increasing the gravity force will increase the sedimentation rate of algal cells and is attainable by applying centrifugal forces on algal suspensions.

\section{MICROALGAE FLUCCULATION}

Addition of chemicals to algal cultures in order to induce algae flocculation is a routine procedure in various separation technologies as: sedimentation (Friedman et al. 1977, Mohn 1980), flotation (Moraine et al. 1980), filtration (Mohn 1980 \& 1978) and centrifugation (Golueke \& Uswald 1965, Moráine et al. 1980). Therefore, a brief discussion is dedicted herein to algal flocculation methods and flocculants.

The various chemicals which were studied as algal flocculants can be broadly divided into two groups: a) inorganic agents including polyvalent metal ions as $\mathrm{Al}^{+3}$ and $\mathrm{Fe}^{+3}$ which form polyhydroxy complexes at suitable pH as shown in figure 2.1.3. Lime $\left(\mathrm{Ca}(\mathrm{OH})_{2}\right)$ flocculation is a common technique in water and wastewater treatment. It involves raising the $\mathrm{pH}$ with 1 ime to the point at which $\mathrm{Mg}(\mathrm{OH})_{2}$ is formed and acts as a ultimate flocculant (Folkman \& Wachs 1973 , Friedman et al. 1977). b) Polymeric organic flocculants which may be anionic, cationic and non ionic. The term polyelectrolyte is generaliy used to describe polymeric flocculants including the 
nonionic species, synthetic and natural polymers (Stumm \& Morgan 1981) as is shown in Table 3.1 .

Various flocculants were evaluated either by batch flocculation experiments ("Jar tests') or by pilot scale apparatus. Table 3.2 summarizes the different flocculants which were tested for algal flocculation and their operating conditions, primarily pH and optimal dose as reported in the literature.

Alum, $\mathrm{Al}_{2}\left(\mathrm{SO}_{4}\right)_{3} \times 16 \mathrm{H}_{2} \mathrm{O}$ or other saits of aluminium were used as flocculants in many branch and field scale experiments (Colueke \& Oswald 1965, Mcaarry et al. 1970, Moraine et al. 1980). Ferric sulfate was used too, but found to be inferior in comparison with alum, regarding the optimal dose, $\mathrm{pH}$ and the quality of the resultant water and slurry (bare et al. 1975, horaine et al. 1980).

Table 3.1 - Some Synthetic and Natural Polymeric Flocculants.

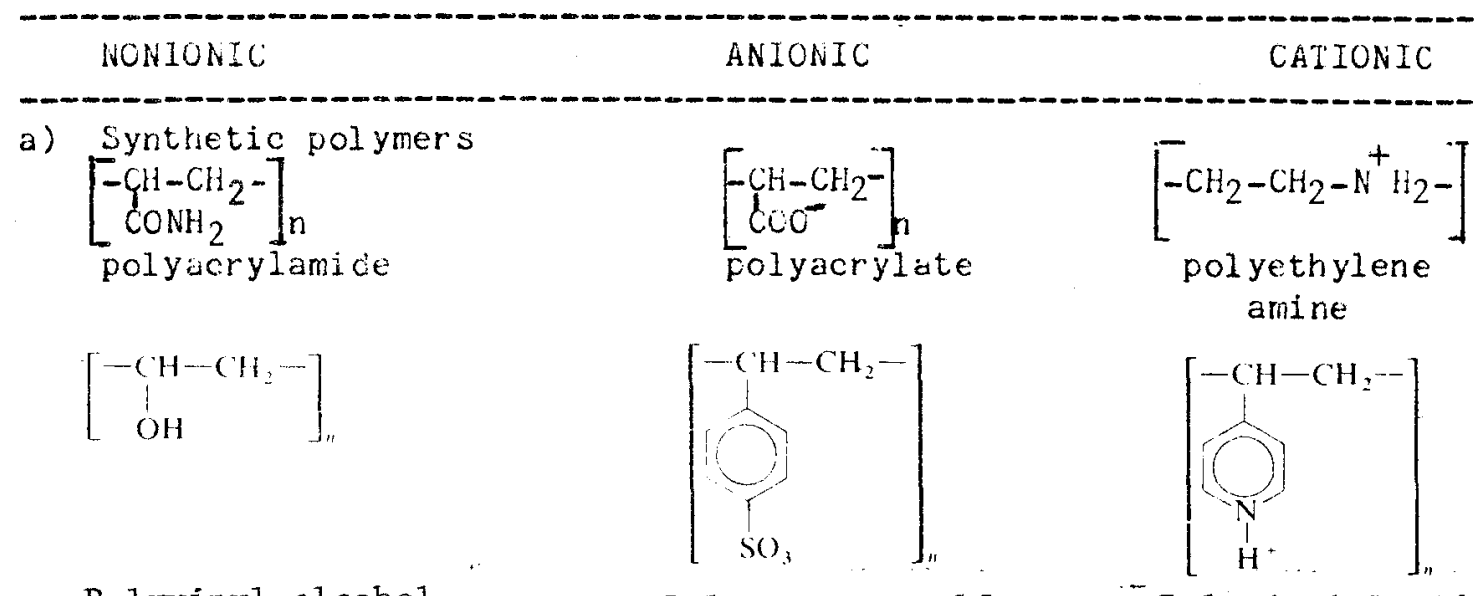

Polyvinyl alcohol

b) Natural polymers
Polystyrene sulfanate "Polyvinyl Pyridinium

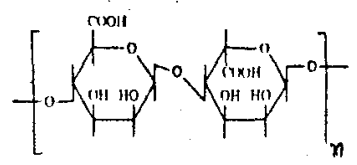

$$
\text { alginate }
$$

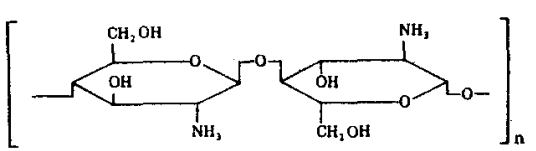

chitosane 


\begin{tabular}{|c|c|c|c|c|c|c|}
\hline FLOCCULANT & TYPE & $\begin{array}{c}\text { OPTIMAL DOSE } \\
\mathrm{mg} / 1\end{array}$ & OPTIMAL $\mathrm{pH}$ & TESTING SCALE & NOT'IS & REFERENCES \\
\hline Alum $\mathrm{Al}_{2}\left(\mathrm{SO}_{4}\right)_{3} \cdot 18 \cdot \mathrm{H}_{2} \mathrm{O}$ & $\begin{array}{l}\text { Polyvalent metal } \\
\text { ion }\end{array}$ & $80-250$ & $5.3-5.6$ & $\begin{array}{l}\text { Sedimentation \& } \\
\text { flotation batch } \\
\text { Exper. Pilot scale } \\
\text { experiments }\end{array}$ & $\begin{array}{l}\text { wastervater } \\
\text { system }\end{array}$ & $\begin{array}{lc}\text { Moraine et a1. } & 1980 \\
\text { Eriedman et a1. } & 1977\end{array}$ \\
\hline Ferric suifate & $\begin{array}{l}\text { Polyvalent matal } \\
\text { ion }\end{array}$ & $50-90$ & $3.0-9.0$ & $\begin{array}{l}\text { batch and pilot } \\
\text { flotation units }\end{array}$ & $\begin{array}{l}\text { clean and } \\
\text { wastewater } \\
\text { systems }\end{array}$ & $\begin{array}{l}\text { Funk et a1. } 1968 \\
\text { Bare et a1. } 1975\end{array}$ \\
\hline $\begin{array}{l}\text { Lime treatment } \\
\text { induces } \mathrm{Mg}(\mathrm{OH}) \\
\text { precipitation } \\
\text { Cationic polymers }\end{array}$ & $\begin{array}{l}\text { positively charged } \\
\text { metal hydroxide } \\
\text { precipitates }\end{array}$ & $500-700$ & $10 \cdot 5-11 \cdot 5$ & $\begin{array}{l}\text { batch sedimenta- } \\
\text { tion experiments }\end{array}$ & $\begin{array}{l}\text { wastewater } \\
\text { systems }\end{array}$ & $\begin{array}{l}\text { Folkman \& Wachs } 1974 \\
\text { Friedman et al. } 1977\end{array}$ \\
\hline Purifloc & - & 35 & 3.5 & batch & $\begin{array}{l}\text { wastewater } \\
\text { syscens }\end{array}$ & Moraine et al. \\
\hline Zetay 51 & polyethylene amine & 10. & $>9$ & batch & $"$ & $" 1$ \\
\hline Dow $21 \mathrm{M}$ & Polyethylene amine & 10 & $4-.7$ & batch & $\begin{array}{l}\text { clean } \\
\text { system }\end{array}$ & Tilton et al. \\
\hline Dow C31 & Polyamine & $1-5$ & $2-4$ & batch & $\begin{array}{l}\text { clean } \\
\text { system }\end{array}$ & Tenny et al. \\
\hline Chitosan & $\begin{array}{l}\text { diacetylated polymer } \\
\text { of chitin. }\end{array}$ & 100 & 8.4 & batch & $\begin{array}{l}\text { clean } \\
\text { sysrem }\end{array}$ & $\begin{array}{ll}\text { Venkataraman et al. } & \\
& 1980\end{array}$ \\
\hline
\end{tabular}

Table 3.2 - Different flocculants and their optima ( $\mathrm{pH}$ and dose) for algae flocculation. 
Although good clarification of algal pond effluent has been achieved by lime treatment (Folkman \& Wachs 1973, Shelef et al. 1978, Friedman et al. 19/7) that flocculant is restricted to cultures which contain magnesium concentration above $10 \mathrm{mg} / \mathrm{l}$ and the resultant sludge consisted more oi lime than of algae, containing up to $25 \%$ calcium.

Crganic polymers were tested as algal flocculant on batch scale. Only the cationic polymers were found as efficient flocculants (Teriny et al. 1968, Tilton et al. 1972, Horaine et al. 1980). In adition polymers can be used in conjunction with alum or ferric sulfate to improve the separation process, while anionic polymers improve lime flocoulation (Friedman et al. 197i).

Tenny et al. (1968) and Tilton et al. (1972) explained cilgal polymeric illocculation by adsorption and bridging model and studied few parameters which affect the phenomena. Low molecular weight cationic polymers either do not cause any flocculation or are required in very high concentrations. At higher molecular weight polymers the optimal dose will decrease with increasing nolecular weight, however, very high molecular weight polymer will reversed the algal surface charge and stavilize the suspension (Tilton et al. 1972). The hydrogen ion concentration as well as medium electrolite concentration influence the surfide charge density of the algal surface, the degree of ionization charge density and the extention of the polymer and subsequently the whole flocculation process. Variations in algal concentrations (algal surface area) would influence the concentration of polyelectrolyte required for a given degree of flocculation and there is a definite stechiometry between algal concentration and polymer cosage for algal flocculation (Tenny et al. 1969). 
The chemical composition of algal medium may affect the flocculation optima (i.e. dose and $\mathrm{pH}$ ). For lime treatment process where $\mathrm{Mg}(\mathrm{OH})_{2}$ precipitates and act as a flocculant, it was found that the higher dissolved organic substances (measured by, COD) in the algal suspension, the higher was the dose of $\mathrm{Hg}(\mathrm{OH})_{2}$ required for good flocculation of the algae (Folkman \& Wachs 1973). Inhibition of flocculation processes caused by the presence of dissolved organic substance of biologic origin was observed by other invstigations as well (Hoyer \& Bernhardt 1980, Narkis \& Rebhun 1981). On the other hand, Tenny et al. (1969) showed that algal exocellular organic substances decrease the optimal flocculant dose during the early declining growth phase, whereas accumulation of these substances during the late growth stages increases the optimal dose evidently due to the organics which serve as protective colloid.

Moraine et al. (1980) pointed out that the soluble $\mathrm{PO}_{4}$ concentration is an important factor which influence the alum optimal dose. The required dose of alum may be described by

$$
\mathrm{Al}+3=\left(\mathrm{PO}_{4}^{-3}\right)_{\mathrm{S}}+\mathrm{k} \cdot(\mathrm{TSS})
$$

where $\mathrm{Al}^{+3}$ is the alum dose $\mathrm{mll},\left(\mathrm{PO}_{4}^{-3}\right)_{\mathrm{S}}$ the soluble phosphate $\mathrm{mN}$, TSS, the suspended solid concentration $g / 1$ and $k$ is alum specific dose $m$ mole Al ${ }^{+3} / g$ TSS. The coefficient $k$ should be a function of effluent characteristics. However, it was not correlated with such parameters as alkalinity, $\mathrm{NH}_{3}, \mathrm{BOD}$, but weakly correlated with temperature and algal type (Shelef et al. 1981). 
The many variables which affect the flocculation process make the prediction of the operational conditions impossible and they should be evaluated by bench scale experiments as 'jar test'.

The apparent spontaneous floc formation and settling of microalgae has been mentioned in the literature for two decades. The phenomenon was termed 'autoflocculation'. In some cases this phenomenon is associated with elevated $\mathrm{pH}$ due to photosynthetic $\mathrm{CO}_{2}$ consumption corresponding with precipitation of inorganic precipitates mainly calcium phosphate which cause the flocculation (Sukenik \& Shelef in press). Aside from this coprecipitative autoflocculation, the formation of algal aggregates can also be due to: a) excreted organic macromolecules (Pavoni et al. 1974, Benemann et al. 1980), b) inhibited release of microalgae daughter cells (Arad et al. 1980) and c) aggregation between microalgae and bacteria (Kogura et al. 1981).

\section{ALGAE HARVESTING TECHNOLOGIES}

Solid-liquid separation processes can be classified into two kinds of separation. (Svarovsky 1979a). In the first, the liquid is constrained in a vessel and particles can move freely within the liquid. Sedimentation and flotation fall into this category. In the second kind, the particles are constrained by a permeable medium through which the liquid can flow. Filtration and screening can fit this definition. Fig. 4.1 shows further sub-divisions within both of these categories. Density difference between the solids and the liquid are needed for gravity or centrifugal sedimentation. 


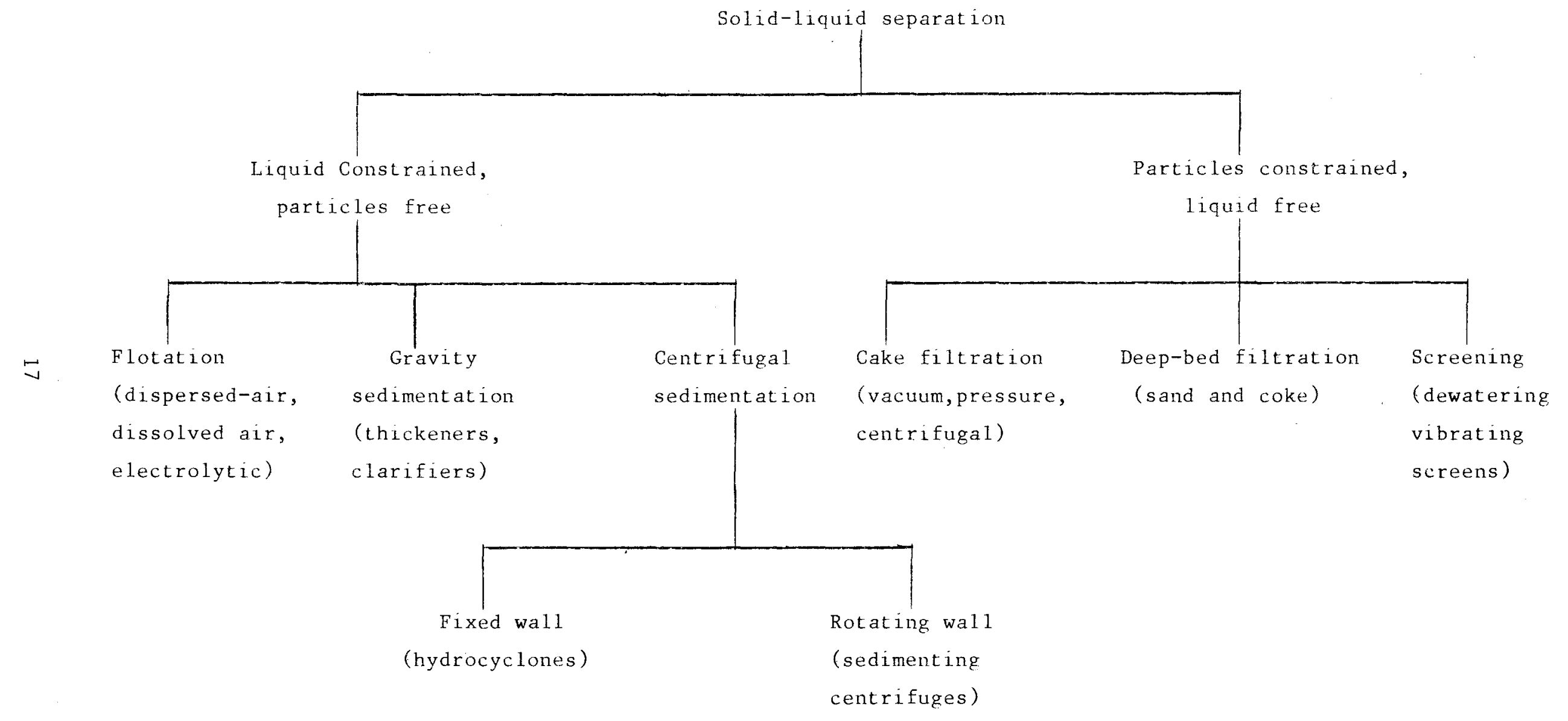

Figure 4.1: Classification of common industrial solid-liquid separation techniques 


\subsubsection{Background}

Filtration and screening processes both separate solids from liquids by passing a suspension through permeable medium that retains the solids.

\section{Screening}

The principle of screening is introducing particles onto a screen of given aperture size. The particles either pass through or collect on the screen according to their size. Although this method is used primarily for solid-solid separation it is also used for solid liquid separation. For algae harvesting two screening devices were employed: microstrainers and vibrating screen filters.

\section{Filtration}

In all filtration a pressure drop must be applied across the medium in order to force flud to flow through. Depending upon the required magnitude of pressure drop one or more of the following driving force may be employed: gravity, vacuum, pressure or centrifugal.

Two basic lypes of filtration are used:

I. Surface filters - in which the solids are deposited in the form of a cake on the face of a thin filter medium. As soon as a layer of cake appears on the filter face, deposition shifts to cake itself and the medium acls only as a support. As the cake grows, the resistance to flow increases. Thus, for a constant pressure drop the feed rate declines.

II. Depth filters (deep bed filtration) - in which the solids are deposited within the filter medium.

The problem with using filtration to clarify algae pond effluent is that a media fine enough to retain all the algae tend to blind rapidly, requiring frequent backwashing. As a result filter size has

*Filters description and operation mode were taken from "Solids Liquids Separation" by L. Svarovsky, Chemical Eng. July 2, 1979. 
to be increased and solid content of the biomass stream decreases. However, the search for effective and efficient means of filtration continues, due to its potential advantages in reduced cost and energy, and avoidance of chemicals and their impact on feed quality.

Several filtiation methods have been tested with varying degrees of success.

Discussions of filtration and screening procedures for algae harvesting are presented in the following sections.

\subsubsection{Filtration and Screening Devices}

\subsubsection{Pressure Filters}

In pressure filters the driving force for filtration is the liquid pressure developed by pumping or by the force of gas pressure in the feed vessel. Pressure filters can treat feed with concentrations up to $10 \%$ solids. Pressure filters may be grouped into two categories, plate-and-trame filter presses and pressure vessels containing filter elements. (Svarovsk - 1979).

In the conventional, plate-and-frame press a sequence of perforated, square or rectangular plates alternating with hollow frames is mounted on suitable supports and pressed together with hydraulic- or screw-drawn rams. The plates are covered with a filter cloth. The slurry is pumped into the frames and the filtrate is drained from the plates.

The second category of pressure filters includes a number of available designs that feature a pressure vessel containing filter elements, such as rotary-drum pressure filters, cylindrical-element filters, vertical tank vertical leaf filters, horizontal tank vertical leaf filters, and howiantal leaf filters.

Mohn (1980) tested five different pressure filters for Colastrum harvesting: Chamber filter press, Belt press, Pressure Suction Filter, Cylindric sieve and Filter Basket. His results are shown in table 4.1.1. Final TSS concentrations were in the range of 5 to $27 \%$ and the initial concentration was $0.1 \%$. Based on energy consideration, reliability and concentrating capability the chamber filter press, the cylindric sieve and the filter basket were recommended as potetent filtering systems. The belt filter press was not recommended because 
Table 4.1.1 Devices for harvesting through pressure filtration (Mohn - 1980)

$\begin{array}{lll}\text { \%TSS of the } & \text { Energy Consumed } & \\ \text { Device } & \text { per m } & \text { Algae Species }\end{array}$

Chamber filter press

$22-27 \%$

$0.88 \mathrm{kWh}$

Coelastrum


$18 \%$

Pressure Suction

Filter

Cylindric sieve

(pressure cinused by

rotators)

Filter basket

$$
\begin{aligned}
& (15 \mathrm{ppm} \\
& \text { Flocc. }) \\
& 0.5 \mathrm{kWh}
\end{aligned}
$$

Coelastrum

Coelastrum

$0.3 \mathrm{kWh}$

$0.2 \mathrm{kWh}$
Coelastrum
Discontinuous method, very hig reliability

Continuous method, need preconcentrating of Flocculant, low reliability

Discontinuous Method, good reliability

Continuous method, good reliability

Discontinuous method, for preconcentrating, good reliabil 
the cake obtained without flocculants to the preconcentrate was not dense enough. Pressure suction filter was not recommended because of insufficient information on operational expenses and because of low filtration ratio and high investment costs.

\subsubsection{Vacuum Filters}

In vacuum filters the driving force for filtration results from the application of a suction on the filtrate side of the medium. Although the theoretical pressure drop available for vacuum filtration is $100 \mathrm{kPa}$ in practice it is limited to 70 or $80 \mathrm{kPa}$. In applications where the proportion of fine particles in the feed slurry is low, relatively cheap vacuum filters can yield cakes with moisture contents comparable to those of pressure filters. Furthermore this category includes the only truly continuous filters built in large sizes that can provide for washing, drying and other process requirements.

Vacuum filters are usually classified as either batch operated or continuous (Svarovsky - 1979). The two most common batch-vacuum filters are the vacuum-leaf filter and the vacuum-Nutsche (or batchbed) filter. Both are inexpensive and very versatile, and can cope with frequent changes in process conditions.

The vacuum-leaf, or Moore filter, consists simply of a number of rectangular leaves manifolded together and connected to vacuum. The leaves, which are carried by an overhead crane during the filtration sequence, are dipped successively in a feed slurry tank, where the filtration takes place, a holding tank, where washing occurs, and a cake-receiving container, where cake discharge is performed, usually by back-blowing.

Simple design, general flexibility, and good separation of the mother liquor and the wash are the important virtues of vacuum-leaf filters. On the other hand, they are also labor-intensive, require substantial floor space, and introduce the danger of the cake falling off during transport.

Vacuum-Nutsche filters consist of cylindrical or rectangular tanks divided into two compartments by a horizontal medium supported by a filter plate. Vacuum is applied to the lower compartment, from which 
the filtrate is collected. The cake is removed manually, or sometimes by re-slurrying.

These filters are particularly advantageous when it is neccessary to keep the batches separate, and when extensive washing is required. They are simple in design, but laborious in cake discharge. They are prone to high amounts of wear due to the digging-out operation. Throughputs are limited. Variations on this kind of filter are: double tipping pan filters, horizontal rotating pan filters and horizontal rotary-tilting-pan filters.

Vacuum belt filters - Another offspring of the pan filter was the horizontal-belt filter, a row of vacuum pans arranged along the path of an endless-belt filter cloth. No longer used, this type has been superseded by the horizontal endless-cloth vacuum filter, which resembles a belt conveyor in appearance. The top strand of the cloth is used for filtration, cake washing and drying. The bottom return strand is for tracking and washing of the cloth.

Horizontal-belt filters are classified according to the method employed to support the filter medium.

One common design is typified by a rubber belt mounted in tension. The belt is grooved to provide drainage toward its center. Covered with cloth, the belt has raised edges to contain the reed slurry, and is dragged over stationary vacuum boxes located at the belt center. Wear caused by friction between the belt and the vacuum chamber is redueed by using replaceable, secondary "wear" belts made of a suitable material such as PTFE, terylene, etc.

These filters are available in large capacities with areas up to $200 \mathrm{~m}^{2}$ or more. They can be run at very high belt speeds when handing fast-filtering materials such as mineral slurries. The main disadvantages of rubier-belt filters are the high replacement cost of the belts, the relatively low vacuum levels, and limitations on the properties of the rubber in certain solvents.

Another type of horizontal-belt filter uses reciprocating vacuum trays mounted under a continuously traveling filter cloth. The trays move forward with the cloth as long as the vacuum is applied and return quickly to their original position after the vacuum is released. This 
overcomes the problem of friction between the belt and the trays, because there is no relative movement between them while the vacuum is being applied. The mechanics of this filter are rather complex and expensive, however, and require intensive maintenance. A range of solvents can be used. Widths up to $2 \mathrm{~m}$ and areas up to $40 \mathrm{~m}^{2}$ are available.

The indexing-cloth machines are a further development along these lines. In these, the vacuum trays are stationary, and the cloth is indexed by means of a reciprocating discharge roll. During the time the vacuum is applied, the cloth is stationary on the vacuum trays. When the vacuum is cut off and vented, the discharge roll advances rapidy, moving the $c$ loth forward $500 \mathrm{~mm}$. The cycle is then repeated.

As with reciprocating-tray types, the cloth can be washed on both sides. Cake discharges by gravity at the belt's end when it travels over the discharge roll.

The major advantages of this filter are its simple design and low maintenance costs. The main disadvantage is the difficluty of handing very fast-filtering materials on a large scale.

Rotary vacuum filter - All of the vacuum filters covered so far, with the exception of the vacuum-leaf filter, use a horizontal filtering surface (top feed). This arrangement offers the following advantages:

1. Gravity filtering can take place before the vacuum is applied. In many cases this may prevent excessive blinding of the cloth.

2. Heavy or coarse materials can be filtered without problems due to settling.

3. Fine-particle penetration through the medium can be tolerated because the filtrate can be re-cycled back onto the belt. Coarse material separated there can then serve as a pre-coat.

4. Top-feed filters are ideal for cake washing, cake dewatering, and other process operations such as leaching.

5. A high degree of control can be exercised over cake formation. Allowances can be made for changed feeds and/or different cake-quality requirements. This is particularly true of many horizontal-belt filters. With these units the relative proportions of the belt 
allocated to filtration, washing, drying, etc., as well as the belt speed and vacuum quality, can be altered easily to suit process changes.

There are, however, two major drawbacks:

1. They require large floor area.

2. Their capital cost is high.

With the exception of the indexing belt filter, a saving in installed cost of about $25 \%$ can be made by substituring a rotary-drum filter. But the cost of doing so is losing many of the above-ment loned advantages.

The rotary-vacuum fiter (in particular the rotary-vacuum-drum filter or RVDF) is still the most popular vacuum filter today.

The drum rotates slowly about its horizontal axis and is partially submerged in a slurry reservoir. The perforated surface of the drum is divided into a number of shallow, longitudinal sections about $20 \mathrm{~mm}$ deep. Each section is an individual vacuum chamber, connected through piping to a central outlet valve at one end of the drum. The drum surface is covered with a cloth filter medium and the filtration takes place as each section is submerged in the feed slurry.

Filtration can be followed by dewatering, washing and maybe also drying. In use are several different systems of cake discharge, all of which can be assisted by air blowback: simple-knife discharge, advancing-knife discharge (with precoat filtration), belt or string discharge, and roller discharge.

Mohn(1980) tested five different vacuum filters for the farvesting of coelastrum: vacuum drum filter not precoated, vacuum drum filter precoated with potato starch, suction filter, belt filter and filter thickener. His results are shown in table 4.1.2. Final TSS concentrations were in the range of 5 to $37 \%$ and the initial concentration was $0.1 \%$. Based on energy consideration, reliability and concentrating capability the precoated vacuum drum filter, the suction filter and the belt filter were recommended. The precoated filter can also be used for harvesting of tiny microalgae like Scenedesmas. The none precoated vacuum drum filter had a low reliability. After 15 
Table 4.1.2 Devices for harvesting through vacuum filtration

\%TSS of the Energy Consumed

Device

concentrate

per $m$

Algae Species

Remarks

None precoated

vacuum drum filter

Potato starch

precoated vacuum

drum filter

Suction filter

(vacuum by a $<\mathrm{m}$

water column?

Belt filter

Filter thickener
$18 \%$

$37 \%$

$8 \%$

$9.5 \%$

$5-7 \%$
$5.9 \mathrm{kWh}$

$-$

$0.1 \mathrm{kWh}$

$0.45 \mathrm{kWh}$

$1.6 \mathrm{kWh}$
Coelastrum

Coelastrum

+ Scenedesmus

Coelastrum

Coelastrum

Scenedermus +

Coelastrum
Continuous method, low reliability

Continuous method

iscontinuous method

Continuous method for preconcentration; good reliability

Discontinuous method for preconcentration method low reliabiltiy 
minutes filtration time the filter cloth was consistently clogged. Vacuum filtration without precoat was found to be ineffective for the accelerated pond effluent in the Technion. (Shelef - 1981).

The filter thickeners were not recommended because of low density of the concentrate ( $3-7 \%$ TSS), low filtration velocity, high energy demand, and inconsistent reliability.

Dodd (1972) was the first to harvest microalgae by a belt filter precoated with eucafyptus and pine krafts fibers. The use of a precoat was found to cause indesirable operational complexity and increased costs. Fine weave cloth rather than the precoated filter was investigated in Sirgapore (Dodd - 1980). This method required a relatively low energy input and no chemicals. It was found to be efficient when harvesting the larger species of algae such as Micractinium, but had problems of blinding with the smaller species such as Chlorella. Its capital costs are higher than dissolved air floatation but the operating expenditures are the lowest of any harvesting technigue with the exception of natural settling. (Dodd 1980),

\subsubsection{Microstrainers}

Microstrainers consist of a rotary drum covered by a straining fabric, stainless steel or polyester. A backwash spray collects the particles onto an axial through. The unit, cost of microstraining is low, from $\$ 5$ to $\$ 15 / 10^{6} 1$ depending on scale and some specific assuniptions. (Beneman et al, 1978). For larger algae even lower costs may be achieved. Advantages of microstrainers are: simple function and construction, easy operation, low investment, negligable attrition due to ebsence of quickly moving parts, low energy consumption, and high filtration ratios.

Problems encountered with microstrainers include incomplete solids removal and difficulty in handing solids fluctuations. These problems may be partially overcome by varying the speed of rotation. (Middlebrooks, Porcella et al - 1974). Another problem associated with microstrainers is the buildup of bacterial and algae slime on the microfabric. This growth may be inhibited by using ultraviolet 
irradiation equipment. However, microstrainers may require periodic cleaning.

Microstrainers have been widely used in the elimination of particulate matter from effluents of sewage works, (Bodien Steinberg 1969, Diaper - 1969, Hanisch - 1974) and in removal of algae from water supplies (Berry - 1966). Despite this, they have usually failed when applied to oxidation pond effluents (Golueke and Oswald - 1965). Van Vurren (1960) reported successful removal of Micractinium from algae ponds in South Africa, but, when an uncellular strain of Schenedesmus and chlorella overtook the ponds, algae removal became very poor. At the istitute for biotechnology in Dortmund microstrainers were found to concentrate Coelastrum proboscideum to about 1.5\% TSS. (Mohn 1980). operational expenses amounted to about DM $0.02 / \mathrm{m}^{3}$ at an energy consumption of $0.2 \mathrm{kWh} / \mathrm{m}^{3}$. Koopman, Benemann and Oswald (1978) achieved some success in clarifying high rate pond effluent with rotating microstrainer with continuous backwash. Their success was limited to effluent of ponds dominated by algae growing in cenobia such as Micractinium and Schenedesmus, since the finest screens available to them at that time had $23 u m$ openings, and they were not able to maintain the dominance of such a population for long even by recycling most of the separated algae.

Tests in the Technion with a prototype rotary microstrainer equipped with $23 \mu \mathrm{m}$ nylon mesh gave similar results, and since frequently there were algae present as single cells or smaller cenobia, clarification was not consistently satisfactory (Shelef - 1981 ). Recently polyester screens as fine as $1 \mu \mathrm{m}$ have become available. (Cravens and Lauritch - 1980, Cravens and Kormanik - 1978, Kormanick and Cravens - 1978). Wittman and Cravens - 1980 have reported success in clarifying stabilization lagoon effluent in such rotary microscreens, reducing TSS from up to $80 \mathrm{mg} / 1$ to $20 \mathrm{mg} / 1$ or less.

Clarification with microstrainers $(6 \mu, 1 \mu)$ in the Technion ponds effluent (Shelef - 1981) showed a good algae removal from the Francea Micractinium pond, and quite poor clarification for the Chlorella pond. The difference was evidently due to the difference in size of the algae in each pond. Whereas the Francea were completely retained even by the 
$6 \mu$ screen and served as filter-aid for smaller algae present, the Chlorella passed even through the $1 \mu$ screen, although their diamiter exceeded $1 \mu \mathrm{m}$. More experiments should be done to determine whether there was a problem of screen size control, passage of small cell fragments, or whether Chlorella really was not retained by such a screen. Continuous operation may overcome part of the problem by building up and maintaining a controlled precoat layer of algae.

\subsubsection{Vibrating Screen Filters}

Vibrating screen filters are used in many industries like the paper or food industry. It is also used in municipal sewage plants to concentrate sewage (Liedtke 1977). At Sede Boker (Ben Gurion University, Israe1), Vibrating screens are used for separating Spirulina.

At Dortmund Coelastrum was harvested by vibrating screen filters (Mohn - 1980). Discontinuous1y harvesting increased the TSS to $7-8 \%$ and continuous operation increased the TSS to $5-6 \%$ - but the former complicated the removal of the slurry.

\subsubsection{Cartridge Filters}

These are filters that use an easily replaceable cartridge made of paper, cloth or various membranes having pore size down to $0.2 \mu \mathrm{m}$. The suspension is simply pumped, sucked, or gravity fed through the filter.

In order to keep down the frequency of cartridge replacement, cartridge filtration is almost always limited to polishing of liquids with solids contents less than $0.01 \%$ by weight.

\subsubsection{Deep-bed Filtration}

The particles recovered in a depth filter are generally smaller than the pores. Hence, they pass into the medium and are collected within the bed by several deposition mechanisms.

Deep-bed filtration is most often operated as a batch process. During the operating sequence the filter will exhibit a gradual increase in pressure drop as the particles are deposited. When the 
pressure drop reaches the maximum available, the filter must be taken out of service for cleaning. This is usually done by reverse flow backwashing. Deep bed filters were originally developed for potablewater treatment, where they served as the final polishing step. More and more they are being applied to industrial wastewater treatment.

Reinolds et al (1979), and Harris et al (1978) reported successful clarification of stabilization pond effluent by intermediate sand filtration, but TSS concentration of their effluent did not reach 100 $\mathrm{mg} / \mathrm{l}$, and was only $30 \mathrm{mg} / \mathrm{l}$ on average. With Technion accelerated pond effluent sand, filters clogged within 15 minutes and filtration rate has fallen close to zero.

Intermittent sane filtration was tested as a process to upgrade existing wastewater treatment facilities in Utah. (Middlebrooks and Marshal1 - 1974, Marshall and Middlebooks - 1973). The results showed good effluent quality: $5 \mathrm{mg} / \mathrm{l}$ BOD and less than $5 \mathrm{mg} / \mathrm{l}$ suspended solids concnetration. Only large algae can be harvested by deep bed filtration by separating the dried cake from the surface of the bed. Smaller algae penetrate into the medium and can not be separated efficiently.

\subsubsection{Cross-Flow U1tra-filtration (SUF)}

The cross flow ultra filtration system developed by the Israel Desalination Engineering (Zarchin Process) Ltd. was adopted for treatment of algae sewage pond effluents in collaboration with the Technion Environmental Research Center in order to provide a one-stage unit of operation following the algae ponds that would produce high quality effluent for reuse on the one hand, and produce an algae "concentrate" for further uitlization as a source of animal proteins on the other hand. Up to 20 fold concentration of the algae had been reached with very high quality clarified effluent, but the high energy requirements made this method uneconomical. 


\subsubsection{Magnetic Separation}

High gradient magnetic filtration (HGMF) for environmental purposes was used in the past for suspended particles removal and the removai of lieivy metals from wastewater. (Bitton et al - 1974, de Lature - 1973, Okamato - 1974, Okudo et al - 1975). Algae remaoval by HGMF was tested by Mitchell et al (1977) and Yedidia et al (1977). The methods is based on suspending magnetic particles (usually $\mathrm{Fe}_{3} \mathrm{O}_{4}$ magnetite) in the solution. These magnetic particles were coagulated with the algae and the solution was then passed through a magnetic field focused on a porous screen which retained the magnetic looes. Bitton et al - (1975) reported algae removal efficiency of between 55 and $94 \%$ by counts from five Florida lakes by use of alum as a flocculant and a commercial magnetic filter. Yadidia et al (1977) in their batch experiments achieved algae removal above $90 \%$ with $5-13$ ppm FeC1 as primary flocculant and 500-1200 ppm magnetite $\left(\mathrm{Fe}_{3} \mathrm{O}_{4}\right.$ ) as a magnetic seed for laboratory prepared and pond-grown algae suspensions. Reliable cost estimates for comnercial plants are not available as present. 


\subsection{Gravity Sedimentation}

Gravity sedimentation is a process of solid-liquid separation that separates a feed suspension into a slurry of higher concentration and an effluent of substantially clear liquid (Svarovsky 1979b). To remove particles which have reasonable settling velocity from a suspension, gravity sedimentation under free or hindering setting is satisfactory. However, to remove fine particles with a diameter of a few microns and for practicable operation flocculation should be induced to form larger particles which possess a reasonable settling velocity.

Gravity sedimentation of non-flocculated particles is qualtatively described by Stokes' Law (equation 2.2.1). This equation is not applicable for flocculated particles since the flocs have a complicated structure and contain considerable amount of water, thus, making the diameter, shape and density of the floc undefinable and the settling mechanisn complicated. (McCabe \& Smith 1975).

Sedineniation processes are primarly divided into a) clarification where the clarity of the overflow is of primary importance and red suspension is usually dilute and b) thickening where thick underflow is the main purpose and the feed slurry is usually more concentrated (svarovsky 1979b). The first process was suggested for algae separation (Mohn 1980, 1978, Eisenberg et al 1981, Venkataraman et al 1980, Sukenik \& Shelef in press) while the second process was only mentioned as a possibility for algae slurry concentration process (Mohn 1980).

\subsubsection{Clarification in sedimentation tank or pond}

only few reports on algae sedimentation in pond without any flocculation process were puolished. Koopman et at (1980) used isolation of tacultacive oxidation pond from inflow feed to promote water clarification. The use of fill-and-draw operation for secondary pond allowed significant removal of algae from facultative oxidation pond effluent, but the process required a cycle of two to three weeks (Benemann et ai 1980). 
Such secondary ponds were used for algae settling from high rate oxidation pond effluent (Adon \& Lee 1980, Benemann et al 1980). Well clarified effluent and algae slurry up to $3 \%$ TSS were obtained at the secondary ponds due to algae autoflocculation which enhanced the settling velo.ity. The autoflocculation mechanism in these cases is unclear (Eisenberg et al 1981) and is evidently different from the coprecipitative autoflocculation process suggested by Sukenik \& Shelef (in press).

Mohn (1980) reported on flocculant addition to a settling tube in order to promote algae sedimentation. This process was operated discontinuously at intervals of $20 \mathrm{~min}$. per batch and algae suspension was concentrated to $1.5 \%$ TSS.

Algae separation by sedimentation tanks or tubes is considered as an inexpensive process, however, without flocculation its reliability is low (Table 4.2). Algae autoflocculation phenomena shouold be studied and weil understood before cne can incorporate these natural processes in sedimentation tank and use it as an inexpensive reliable a lgae separation method for primary concentration.

\subsubsection{Lame11a type clarification tank}

In this type of clarifier, flat inclined plates are used in a settling tank to promote solids contacting and settling along and down the plates. Corrugated and other plate configurations can also be used. The plates slopes ensure the downgliding of the sediments into a sump from wich they are easily removed by pumping (Svarovsky 1979b, Mohn 1980).

This type of clarifier was used by Mohn (1980) for algae separation. Algae were concentrated to $1.6 \%$ TSS and addition of flocculant was required when tiny algae as Scenedesmus suspension was fed to the separator. Jperational reliability of this method was fair and additional concentration of algae slurry was required. 
Table 4.2 Compaison of microalgae harvesting by Gravity sedimentation methods

\begin{tabular}{|c|c|c|c|c|c|}
\hline Device & $\begin{array}{l}\text { Final slurry } \\
\text { concentration } \\
\% \text { TSS. }\end{array}$ & $\begin{array}{l}\text { Relative } \\
\text { energy } \\
\text { required }\end{array}$ & Reliability & $\begin{array}{l}\text { Recommendable for } \\
\text { algae size group * }\end{array}$ & Remarks \\
\hline Clarification tank & $0.5-3$ & very low & poor & $a+b$ & $\begin{array}{l}\text { flocculant } \\
\text { required }\end{array}$ \\
\hline $\begin{array}{l}\text { Lame lla type } \\
\text { sedimentation tank }\end{array}$ & 1.5 & very low & fair & $a+b$ & $\begin{array}{l}\text { flocculant } \\
\text { required } f c \\
\text { tiny algae }\end{array}$ \\
\hline $\begin{array}{l}\text { Flocculation in } \\
\text { conjunction with } \\
\text { sedimentation tank }\end{array}$ & 1.5 & high & good & $a+b$ & \\
\hline
\end{tabular}

* a - Chlorella type tiny algae

b - Coelastrom; Microactinium type grouped algae 


\subsubsection{Thickener}

Gravitational thickener may be used for final concentration of algae slurry with or without addition of flocculants. However, there is no report in the literature dealing with this device for algae thickening

\subsubsection{Flocculation followed by gravity clarification}

Golueke \& Oswald (1965) in a pioneering study suggested that flocculation process followed by gravity clarification, as it is practiced in waste water treatment plants (Metcalf \& Eddy - 1974), is a reliable method for algae separation. They used alum as a flocculant and after gravity clarification removed up to $85 \%$ of the suspended biomass from the high rate oxidation pond. Various algae species could be separated by this reliable method to give an algae slurry of $1.5 \%$ TSS (Table 4.2). A comparison of this separation method with flocculation flotation method (Moreine et al. 1980, Friedman et al. 1977) shows that the last one has an advantage of very sharp optima for clarification.

\subsection{Flotation}

Flotation is a gravity separation process based on the attachment of air or gas bubbles to solid particles, which then are carried to the liquid surface and accumulate as float which can be skimmed off.

The success of flotation depends on the instability of the suspended particles. The lower the instability the higher the air particle contact. The attachment of an air bubble to a particle depends on air, solid and aqueous phases contact angle and is described by equation 4.3 .1

$$
\sigma_{A S}=\sigma_{W S}+\sigma_{W A} \cos \alpha_{i}
$$

where $\sigma$ is the interfacial tension between air soil (AS), water soil (WS) and the water air (WA), $\alpha_{i}$ is the contact angle formed between the air water boundary and the water solid boundary.

If $\sigma_{A S}>\sigma_{W A}$ the contact angle is greater than zero and the air bubble adheres to the solid. The larger the contact angle the greater the tendency of air to adhere. 
Substances which are effective in changing interfacial tensions surface active agents, may be used to modify the interfacial tension of the solid and to change the contact angle.

The flotation processes are classified according to the method of butble production: dissolved air tlotation, electrolytic flotation (electroflotation) and dispersed air flotation (Svarovsky 1979b, McCabe \& Smith 1974, Metcalf \& Eddy 1975).

In spite of early works (Golueke \& Oswald 1965 and Levin et al 1962) which recommended algae flocculation sedimentation process and discouraged any interest in flotation, Van Vuuren and Van Duuren (1965) reported on partial natural flotation of algae, and extended this observation to a full scale flotation project. (Van Vuuren et al 1965). Since then, it became apparent that flocculation should be floolwed by several hours sedimentation while flotation shortens the duration needed for clarification to only a few minutes. During the last decade several publications reported about the effectiveness of the flocculation flotation process for clarifying algae pond effluents (Bare et al 1975, Bratby \& Marais 1973, Moreine et al 1980, Sandbank et al 1974). Only limited algae removal is achieved by flatation processes (dissolved air and electrolytic) unless flocculant in optimal dose is injected to the algae suspension (Bare et al 1975). 4.3.1 Dissloved air flotation

The production of fine air bubbles in the dissolved air flotation process is based on the higher solubility of air in water as pressure increases. This can be achieved in three ways: saturation at atmospheric pressure and flotation under vacuum, saturation under static head with flow upward resulting in bubble formation (microflotation) and saturation at pressures higher than atmospheric and than flotation under atmospheric conditions (Svarovsky 1979b).

The last mentioned version (Fig. 4.3) is the only one that was examined and used for algae separation since its low construction and maintenance costs (Sandbank 1979). Algae separation by dissolved air flotation should be operated in conjunction with chemical flocculation (Bare et al 1975, McGarry \& Durrani 1970b). The effluent clarification 


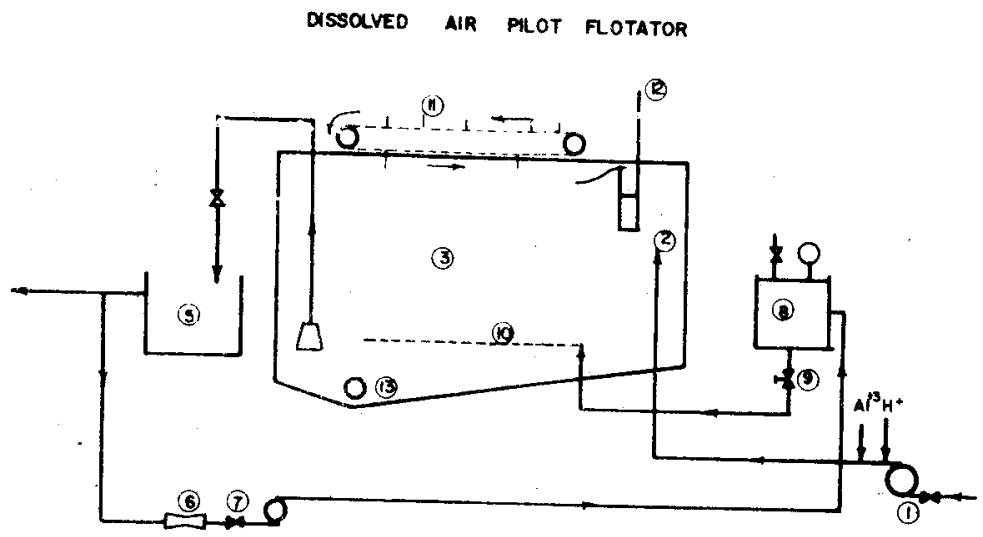
1 (1) PONE EFFLUENT PUMP
(2) FloceUlation SEction
(7) RECYRCULATION PLAP
(3) FLOTATION SECTION
(c) PaEssunizwg tanu
(4) CLafied EFFLUENT INTAKE
(5) FLOTATOA EFFLUENT
(6) verturi
(9) Pressure release VALVE
(10) AIR DIFFUSER
(ii) SKIMUER
(12) ALEAL FLOAT THOUBH
(3) DRAIN

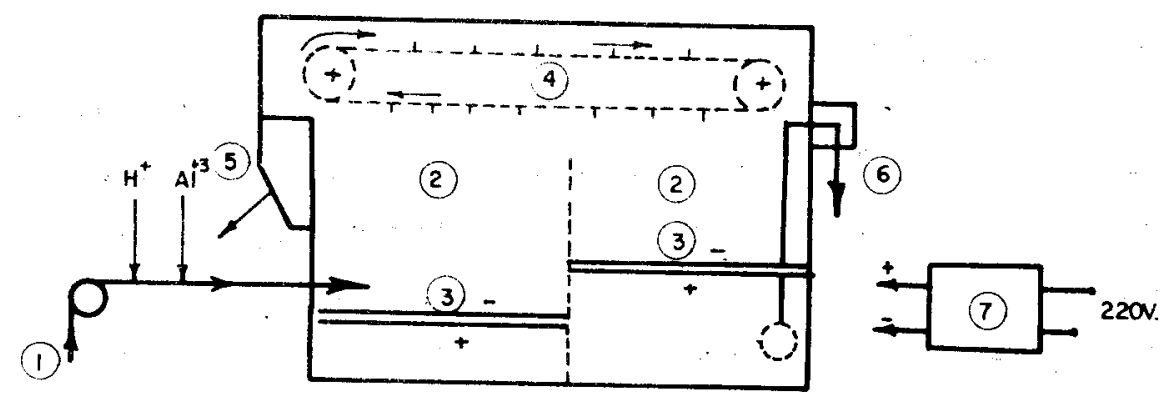

(1) PONO EFFLUENT INLET

(3) FLOTATION ZONE

(3) PAIRS OF ELECTRODES

(4) FLOAT SKIMMER.

(5) AL GAL FLOAT OUTLET

(6) CLARIFIED EFFLUENT SIPHON

(7) D.C. POWER SUPPLY, HIGH CURRENT,

Fig. 4.3 Schematic diagram of pilot flotators used for algae harvesting above: dissolved-air flotator below: electroflotator 
degree depends on operational parameters such as: recycling rate, air tank pressure, hydraulic retention time and particle floating rate (Bare et al, Sandbank 1979), while slurry concentration depends on the skimmer velocity and its height above water surface (Moreine et al. 1980).

Algae pond effluents which contain a wide range of algae species may successfully be clarified by dissolved air flotation device and an algae slurry up to $6 \%$ is obtainabie. The slurry concentration may be increased by allowing a second flotation to accur (Bare et al 1975, Friedman et al 1977, Moreine et al 1980, Viviers \& Briers 1982). Once the operational parameters of dissolved air flotation unit were determined the reliability of the algae separation method is high, but optimal flocculant dose should be estimated for each operation to attain optimal results (Table 4.2). Koopman and Lincoln (1983) studied the autoflotion of algae, after flocculation with alum or C-31 polymer, by photosynthetically produced dissolved oxygen. Algae removal of 80 to $90 \%$ was achieved at overflow rates in the flotation basin of up to $2 \mathrm{~m}$ per hour, with algal float concentrations averaging more than $6 \%$ solids. However, autoflotation phenomena was restricted to dissolved oxygen concentration above $16 \mathrm{mg} / \mathrm{l}$ and failed at lower concentrations.

\subsubsection{Electroflotation}

In this method fine gas bubbles are formed by electrolysis. The anodic electrochemical reaction is

$$
2 \mathrm{Cl}^{-}+\mathrm{Cl}_{2(\mathrm{~g})}+2 \mathrm{e}^{-}
$$

and the catodic reaction is

$$
2 \mathrm{H}_{2} \mathrm{O}+2 \mathrm{e}^{-} \rightarrow \mathrm{H}_{2(\mathrm{~g})}+2 \mathrm{OH}^{-}
$$

The formed chlorine ma be dissolved in water and react with its chemical components. Hydrogen gas which has low solubility in water will float the algae flocs. In such flotation unit (Fig. 4.3) instead of a saturator, a costly rectifier that must be able to supply from 5$20 \mathrm{~V}$ (d.c.) at a current of approximately $11 \mathrm{~A} / \mathrm{m}^{2}$ electrode is required. The potential difference required to maintain the necessary current density for bubble generation depends on the electrical conductivity of the feed suspension. 
Table 4.3 Comparison of microalgae harvesting by flotation methods

\begin{tabular}{|c|c|c|c|}
\hline $\begin{array}{l}\text { Final slurry } \\
\text { concentration }\end{array}$ & $\begin{array}{l}\text { Relative } \\
\text { energy }\end{array}$ & & Recommendable \\
\hline$\%$ TSS & required & Reliability & algae size group \\
\hline
\end{tabular}

algae size group

Remarks

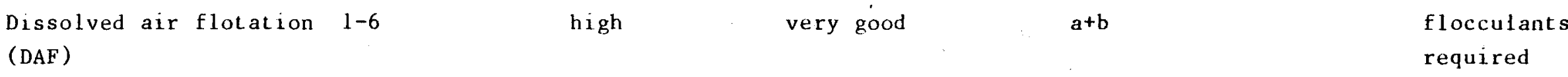

un.

low u.n.
$\mathrm{pH}$ reduction

or surfactants required 
Bench scale studies by Contreras et al (1979) reported on highly efficient electrolytic methods which cause algae flocculation evidently by using the hydroxide formed during electrolysis to cause $\mathrm{Mg}(\mathrm{OH})_{2}$ precipitation and consequently flocculation. Laboratory and field scale electrotictation units for algae removal from wastewater oxidation pond effluent was studied by Sandbank et al (1974), Schwartzbrud (1978), and Kumar et al (1981). A $2 \mathrm{~m}^{2}$ pilot scale unit was operated for clarification of high rate oxidation pond effluent. (Shelef et al 1977). For good clarification alum flocculation should be followed by or done simultaneously with electroflotation, however the last method required shorter retention times (Sandbank et al 1974 )。

Various microalgae species were harvested by this method and the collected algae float contained up to $5 \%$ solids (Table 4.3). Decantation after 24 hours increased the solids concentration to $7-8 \%$ (Shelef et al 1977, Sandbank 1979). The energy requirement of the electroflotation method is high but Svarovsky (1979b) generally noted that for small units of $5 \mathrm{~m}^{2}$ area or less, electric-flotation operating cost is cheaper than that of dissloved air flotation unit.

\subsubsection{Dispersed Aix Flotation}

The process uses large bubbles of about $1 \mathrm{~mm}$, which are produced by agitation combined with air injection (froth flotation) or by bubbling air through porous media (foam flotation). Process selectivity is based on the relative wettability of solid surface. Only particles having a specific affinity for air bubbles rise to the surface (Svarovsky 1979b). Wettability and frothing are controlled by three classes of chemical reagents: a) Frothers which provide stable froth. b) Collectors (promoters) are surface-active agents that control the particle surface wettability by varying the contact angle and the particles electrokinetic properties. c) Modifiers which are $\mathrm{pH}$ regulators.

Golueke \& Oswald (1965) reported that only 2 out of 18 tested flotation reagents gave appreciable concentration of algae but poor removal efficiency was obtained. However, Levin et al (1962) reported 
a flotation process in which algae harvest is primarily controlled by culture $\mathrm{pH}$. The critical $\mathrm{pH}$ level for their process was 4.0 and is apparently explained by changes in the algae surface characteristics.

Flotation of other microorganisms (bacteria) was suggested as a classification and separation process. Gaudin et al (1962) found the E. coli may be floated successfully with $4 \% \mathrm{NaCl}$. In other cases quarternary ammonium salts were used as surface-active agents for effective bacterial flotation (Grieves \& Wing 1966). Microalgae were separated from high rate oxidation pond effluent by ozone flotation. An air stream containing ozone gas promotes cell flotation by some modifications of algae cell wall surface and releasing of some surface active agents from algae celis. (Betzer et a1. 1981).

\subsection{Centrifugation}

In the centrifugal separation process the feed is subjected to centrifugal forces which make the solids move through the liquid.

Equipment available for centrifugation is divided into fixed wall devices (hydrocyclone), and rotating wall devices (sedimenting centrifuges). Further classification of centrifugal devices is shown in Figure 4.4.1. A sedimenting centrifuge is an imperforate bowl into which a suspension is fed and rotating at high speed. Liquid is removed through a skimming tube or over a weir, while solids remain in the bowl (batch processing) or are continuously or intermittantly removed from 1t. Actually centrifugation is an extension of gravity sedimention where the gravitational acceleration $(\mathrm{g})$ is replaced by the centrifugal acceleration $r \omega^{2}$, where $r$ is the particle distance from the rotation spine and $\omega$ is the angular velocity.

Separation efficiency is mainly affected by the behavior of the smallest particles in the system which may be described by Stokes Law (equation 2.2.1). The particle settling velocity is given by the following equation:

$$
\frac{d r}{d t}=\frac{\omega^{2} r d^{2} \Delta \rho}{18 n}
$$

where $\frac{d r}{d t}$ is the settling velocity and $\Delta \rho$ is the difference between density of the particle and the medium. 


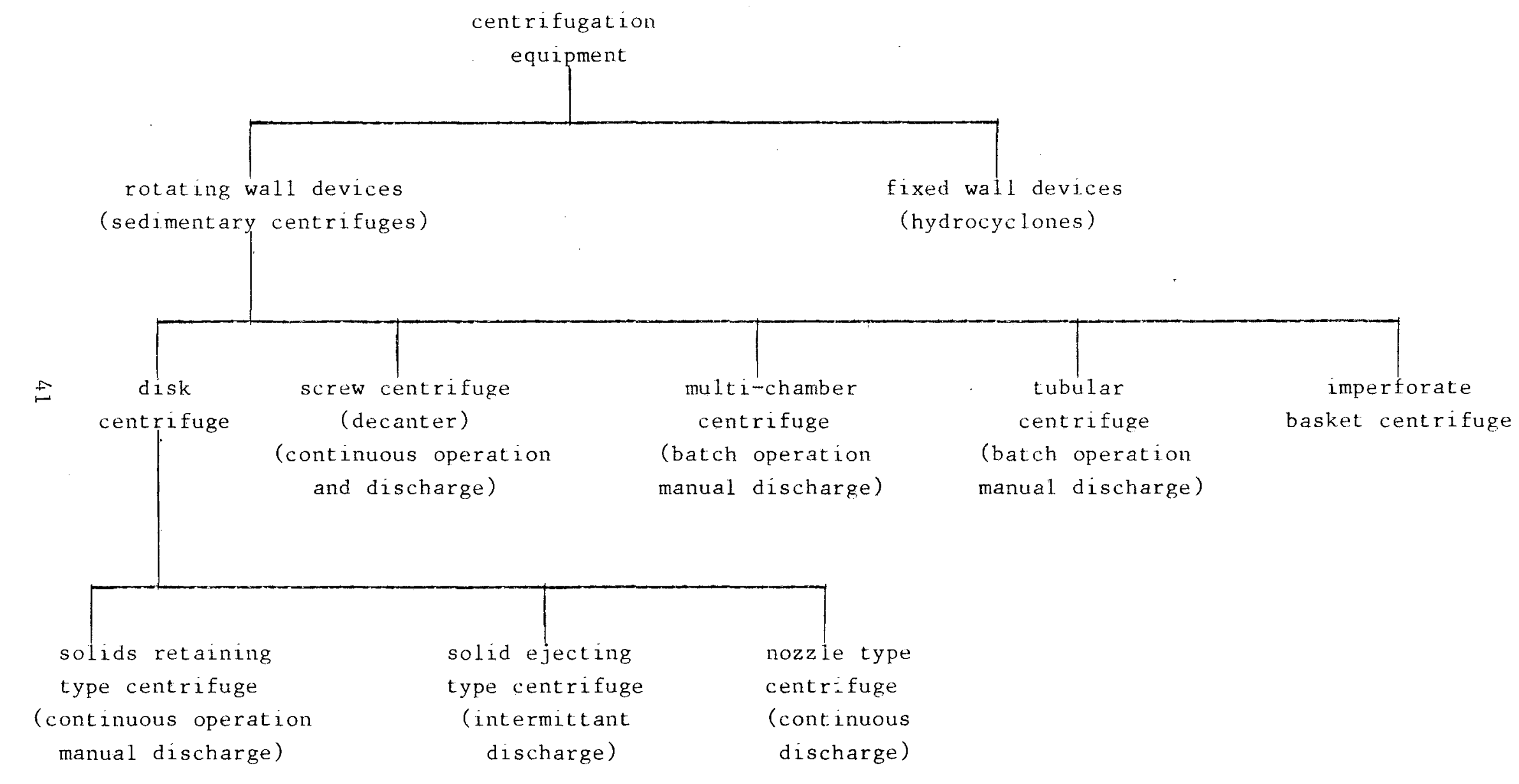

Figure 4.4.1: Classification of centrifugation equipment

(After Svarovsky 1979b) 
The time $t$ required for a particle to settle increases with the settling distances.

$$
t=\frac{s}{(\mathrm{dr} / \mathrm{dt})_{\mathrm{c}}}=\frac{18 \eta \mathrm{s}}{\omega^{2} \mathrm{r} \Delta \rho \mathrm{d}^{2}} \quad 4.4 .2
$$

The total volumetric flow rate $Q$ of a given bowl centrifuge can be calculated according to the sigma concept (quoted by Svarobsky 1,979b) whose basic expression is

$$
\mathrm{Q}=2 \mathrm{~V}_{\mathrm{g}} \cdot \Sigma
$$

where

$$
\Sigma=-\frac{\omega^{2}}{g} \quad \frac{\mathrm{r}_{2}^{2}-\mathrm{r}_{1}^{2}}{\ln \frac{2 \mathrm{r}_{2}^{2}}{\mathrm{r}_{2}^{2}+\mathrm{r}_{1}{ }^{2}}}
$$

and where $L$ is the bowl length, $r_{l}$ is the distance of liquid from the rotation axis, $r_{2}$ is the bowl radius and $V_{g}$ is the terminal settling velocity of the particle in the same liquid under gravity as determined from Stokes' Law in equation 2.2.1.

Several centrifugal devices were examined for potential

application in the algae separation process (Mohn 1980, 1977, Moraine et al 1980, Shelef et al 1977, 1979). Some of them were very efficient as one step separation process while others were found either inefficient or required preconcentrated slurry feed. Other centrifugal devices which are used in various industries were never examined for algae separation or concentration processes. Centrifugal devices which are based on batchwise solid release are of minor atractivity since they have to be stopped and cleaned (most often manually). Although 
some of the centrifugal methods are of high reliability and efficiency one should keep in mind their high operational cost (Table 2) when considering the use of such devices for algae separation. 4.4.1 Tubular centrifuge

This centrifuge is one of the most efficient, with cut sizes below $0.1 \mu \mathrm{m}$ at high speeds. There is however, no provision for solids discharge, thus they have to be stopped and eleaned frequent $1 \mathrm{y}$.. The tubular centrifuges are applicable in bench scale algae harvesting for laboratory studies and for disc centrifuge performance predictions (Moraine et al 1980).

\subsubsection{Multichamber centrifuges}

This device has a closed bowl which is subdivided into concentric, vertical cylindrical compartments that operate in series. Feed is made to pass through zones of progressively higher acceleration. Cleaning of multiple chamber centrifuges should be done manually, a difficult and time consuming procedure (Svarovsky 1979b). Therefore this device does not seem as an attractive equipment for algae harvesting.

\subsubsection{Imperforate basket centrifuge}

The imperforate basket centrifuge is an adaptation of the standard basket centrifuge used for filtration. This device can be operated for separation of solids which make a porous cake. In principle the suspension is fed to a rotating basket having a slotted or perforated wall which is covered with filter medium. Pressure resulting from the centrifugal action, forces the liquid through the filter medium, leaving the solids behind (McCabe \& Smith 1976). Although algae solids do not make a porous cake, this device should be assessed for algae slurry concentration in conjunction with polyelectrolytic flocculation and fine weave filtration medium (see Chap. filtration). 
Table 4.4. Comparison of microalgae harvesting by centrifugation methods

$\begin{array}{llll}\text { Final slurry } & \text { Relative } & \\ \text { concentration } & \text { energy } & & \text { Recommendable for * } \\ \% \text { TSS } & \text { required } & \text { Reliability } & \text { algae size group }\end{array}$

Remarks

$12-22$

very high

very good

$a+b$

one step

plate centrifuge

$2-15$

very high

good

$a+b$

harvesting

nozzle centrifuge

a

one step

harvesting by

slurry feedback

hyd rocyc lone

0.4

very high

low

very high

fair

b

incomplete

requires $2 \%$

slurry feed

* a - Chlorella type tiny algae

b - Coelastrom; Micractinium type grouped algae 


\subsubsection{Decanter}

The scroll type (decanter) continuous conveyor-discharge centrifuge is characterized by a horizontal conical bow 1 . The bow 1 contains a screw conveyor that rotates in the same direction but at a slightly higier speed. Feed enters through an axial tube at the center of the rotor, passes through openings in the screw conveyor and is thrown to the rotor wall. Deposited solids are moved by a Helicical screw conveyor up a sloping beach out of the liquid and discharges.

Mohn (1980)used successfully a screw centrifuge for various algae type slurry concentrations and obtained $22 \%$ TSS out of $2 \%$ TSS algae slurry. The reliability of this device seems to be excellent but the energy consumption is too high.

Shelef et a1 (1977) failed to concentrate $5.5 \%$ algae slurry obtained by algae flocculation flotation process, by a Sl-1 Humbold Bird co-current decanter. However, algae slurry dewatering was improved by reducing relative scroll speed to $5 \mathrm{rpm}$ and algae float following secondary flotation was dewatered from 10 to $21 \%$ TSS. (Shelef et al 1979).

The decanter seems a promising technology for algae slurry concentration and is recommended for further investigation and studies including polyelectrolyte flocculant addition (Shelef et al 1979).

\subsubsection{Solid retaining disc centrifuge}

This is the simplest type of disc centrifuge whose basic concept is to increase settling capacity by using a number of layers in parallel, which is equivalent to the lamella type clarification tank previously mentioned under sedimentation. The disk centrifuge contains a stack of conical disks. Feed enters though the center, liquid flows in thin layers radially inward between the disks toward the outlet, particles settle on the surface of the disk. The particles settling motion is the first and most decisive stage of the separation process, while the second is the downward-outward sliding motion of the particles on the disk surface with subsequent particle impingement on the bowl wall. (Svarovsky 1979b). 
Solid retaining disc centrifuge is designed with a nonperforate bowl wall parallel to the axis of rotation. The frequent cleaning of the bowl makes this type unattractive for algae separation.

\subsubsection{Nozzic type centrifuge}

Continuous discharge of solids as a slurry is possible with the nozzle-type disc centrifuge. The shape of the bowl is modified so that the sludge space has a conical section which provides sufficient storage volume and affords a good flow profile for the ejected sludge. The bowl walls slope toward a peripheral zone containing evenly spaced nozzles. The number and size of the nozzles are optimized to avoid cake buildup and to obtain reasonable concentrated sludge.

The application of nozzle type disc centrifuge was suggested by Goleuke \& Oswald (1965) in their pioneering work for algae harvesting. They studied the relation of nozzle diameter to flow rate, algae removal efficiency and resultant slurry concentration. By comparing this harvesting method to many others they concluded that this one seemed to be promising although economically it is less attractive because of power requirements and capitalization costs. Later on Mohn (1978, 1980) found this device suitable to harvest Scenedesmus somewhat more effectively than Coelastrum. By feedback of the centrifuge underflow he could concentrate the $0.1 \%$ algae suspension by a factor of 150 to $15 \%$ TSS (Table 4.4). The reliability. of this device was good, however care should be taken to avoid clogging of the nozzles.

\subsubsection{Solid ejecting type disc centrifuge}

This centrifuge which is schematically shown in figure 4.4.2, provides intermittant solids ejection. Valve-controlled peripheral ports are regulated by timer or an automatic triggering device. The advantage of this centrifuge for algae harvesting is its ability to produce in a single step, concentrate containing $15-25 \%$ solids with no addition of chemicals. (Mohn 1978, 1980, Shelef et al 1979). This machine concentrated various types of microalgae effectively. and the TSS of the concentrate was between $12 \%$ to $25 \%$ (Mohn 1980, Moraine et al 1980). The degree of the algae suspension clarification increases 


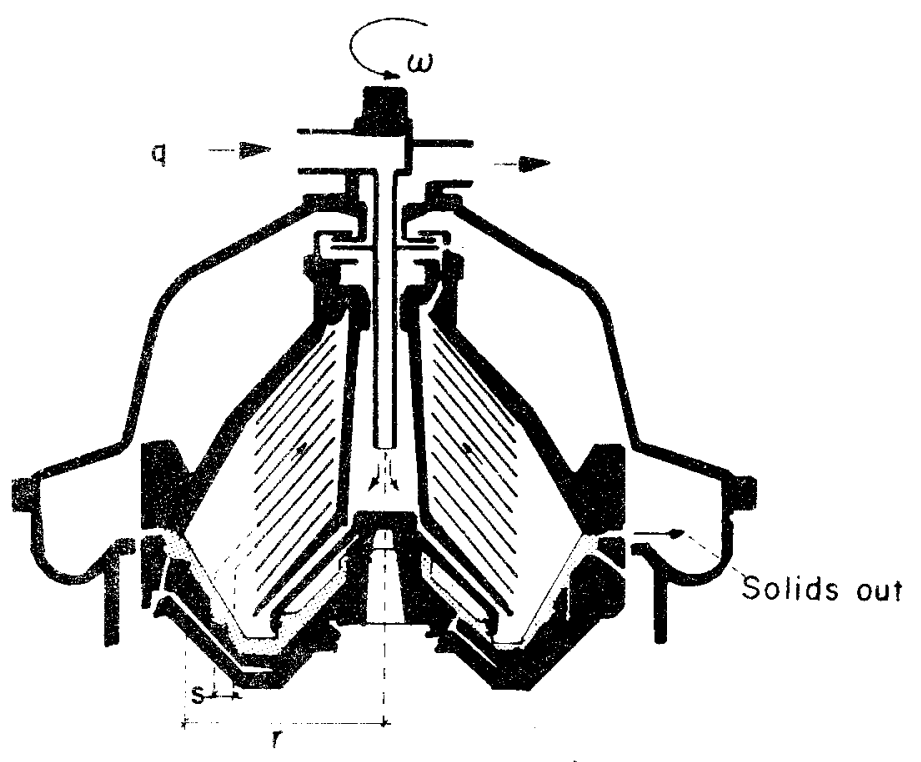

Fig. 4.4.2: Desluager disk centrifuge - schematic diagram 
with increasing residence time (decreasing feed rate) and the ejected solid concentration is affected by the intervals between successive desludging (Shelef et al 1979). This type of centrifuge was found to be very reliable although, solids finer than algae may be retained in the overflow stream, and reduce the clarification degree (Moreine et al 1980). Investment and energy demand $\left(1 \mathrm{kwh} / \mathrm{m}^{3}\right)$ of this centrifuge make this separation method unattractive unless the end product is of high benefit.

\subsubsection{Hydrocyclone}

The hydrocyclone is built of a cylindrical section joined to a conical section. Feed is injected tangentially into the upper part of the cylindrical section and develops a strong swiveling motion within the cyclone. Liquid containing - the fine particle fraction is discharged out through overflow pipe; The remaining liquid containing the course fraction discharges though the underflow orifice at the cone tip (Svarovsky 1979b).

Hydrocyclone was studied for algae harvesting by Mohn (1980). Only Coelastrum which grow in big aggregates is harvested by this means. The resultant algae slurry was low and the clarification of the suspension incomplete (Table 4.4 ). 
5. Algae Drying

The final step in processing algae is usually drying the dewatered slurry to a moisture content of $12-15 \%$. By drying or dehydration, the algal biomass is converted to a stable storable product. Dyhydration poses a problem of major economic importance in that it may constitute $70-75 \%$ of the processing cost. (Mohn 1978). The various systems for drying differ both in the extent of capital investment and ine energy requirements. Selection of the drying method depends on the scale of operation and also the use for which the dried product is intended. Most of the sludge drying methods are used for wastewater sludge and not all of them can be used for algae slurry drying, especially when it is intended to be used for feed.

At this stage of the project it is still unclear whether drying is necessary prior to extracting the lipids from the algae. Anyhow we found it necessary to give at least a short review on this subject. A brief description of the main drying methods is given in the following sections.

\subsection{Flash Drying}

Flash drying is the rapid removal of moisture by spraying or injecting a mixture of dried and undried material into a hot gas stream.

The particles should remain in contact with the turbulent hot gases long enough to accomplish mass transfer of moisture from sludge to the gases. (Metcalf \& Eddy - 1979, EPA Manual - 1979). Flash drying is a common method for wastewater sludge drying and was first applied in 1932 at the Chicago sanitary district. For heat drying of sludge the C.E. Raymond Flash Drying System is most frequently used. 


\subsection{Rotary Dryers}

Rotary dryers use a sloped rotating cylinder to move the material being dried from one end to the other by gravity. Many different dryers have been developed for industrial processes, including direct heatiing lypes in whin the drying material is in contact with the hot gases, indirect heating types, in which the hot gases are separated from the drying material by steel shells, and indirect-direct types in which the hottest gases surround a central shell containing the material but return it at reduced temperatures. (Metcalf \& Eddy 1975, EPA Manual - 1979).

Rotary kiln dryers and drum dryers are the more widely used for heat drying of wastewater sludge. Drum drying is the most common method for algae drying.

Pabst (1975) has shown that dehydrating algae mass with a thin layer drum dryer yield an excellent product from Scenedesmus.

Drying the algae on the drum dryer has the dual advantage of sterilizing the samples and breaking the cell wall. A pilot plant scale model of electrically-heated drum-drying is currently in use. (Becker \& Venkataraman - 1982). The surface area of the drum is $0.5 \mathrm{~m}^{2}$, the evaporation capacity is about $201 / \mathrm{h} / \mathrm{m}^{2}$ of a slurry containing $30 \%$ wet solids. The power consumption is 52KWH. The drying time for Scenedesmus is about $10 \mathrm{sec}$. at $120^{\circ} \mathrm{C}$. Replacement of the electrically heated drum dryer by a steam heated drum dryer could lower the cost of processing Scenedesmus by 6.8 times. According to Soeder and Mohn (1975), $15.7 \times 10^{3} \mathrm{Kcal}$ are needed for evaporating $18.2 \mathrm{Kg}$ of water to obtain $1 \mathrm{Kg}$ of dry algae material with a water content of $4 \%$. Besides this an energy input of $1.4 \mathrm{KWH}$ is needed to run the dryer. Soeder \& Mohn proposed that in order to reduce the high drying cost it is possible to keep the moisture content of the final product at about $10 \%$ rather than 4-5\%. They also proposed that dehydration may be successfully achieved by mixing algae with dry additives such as raw sugar beet pulp, meal powders or grains, producing pellets instead of powder.

Mohn (1978) tested and compared spray drying and drum drying for algae - He recommended drum drying for microalgae bacause of better 
digestibility, less energy requirements, and lower investments. Mohn concentrated the algae to $25 \%$ dry matter. The dryer surface was $2.5 \mathrm{~m}^{2}$ and evaporated up to $50 \mathrm{Kg}$ of water per $\mathrm{m}^{2}$ at a steam pressure of 8 at.

\subsection{Incinerators}

In incineration the temperature of the material to be incinerated is raised to $100^{\circ} \mathrm{C}$, and the water is evaporated from the material before it is ignited; that is, the material is dried prior to ignition. If heat inputs are reduced, the incinerator can be used as a dryer alone.

Multiple hearth incinerator is frequently used to dry and burn wastewater sludges. The furnace is a circular steel cylinder containing several hearths arranged in vertical stack. When the furnace is designed as a dryer only it is needed to provide hot gases, and the material to be dried and gases both proceed downward through the furnace in parallel flow. Parralel flow of product and hot gases is frequently used in drying operations to prevent burning or scorching a heat sensitive material. (Metcalf \& Eddy - 1975).

Another incinerator which is used for sludge incineration is the Dorr 0liver fluidized bed. This system utilizes a fluidized sand bed as a heat reservoir to promote uniform combustion of sludge solids. The fluidized bed is preheated, using fuel oil or gas, before the sludge is introduced. The dryed material is separated form the sand by cyclone separator.

\subsection{Toroidal Dryer}

The toroidal dryer is a relatively new dryer that is employed in the UOP Inc. ORGANO-SYSTEM for sludge processing. It was operated at the Blue Plains wastewater treatment plant in Washington DC for over three years. Another system is installed at UOP's West Chester, Pennsylvania research and development facility. (EPA Manual - 1979). The dryer works on a jet mill principle and contains no moving parts. Transport of solid material within the drying zone is accomplished entirely by high velocity air movement. 
Dewatered sludge with solids concentration of about $35-40 \%$ is mixed with previously dried sludge to reduce to moisture content of the dryer feed.

\subsection{Spray Drying}

Spray drying systems are similar to flash drying systems in that almost instantaneous drying occurs in both. (EPA Matual - 1979). Spray drying involves liquid atomization, gas/droplet mixing and drying from liquid droplets. The atomized droplets are usually sprayed downward into a vertical tower through which hot gases pass downward. Drying is completed within a few seconds. The product is removed from the bottom, and the gas stream is exhausted through a cyclonic dust separator.

Spray drying was found to be a very suitable method for dehydrating algae mass for use as human food. (Richmond - 1983, Soeder - 1980, Hauster - 1980). However this method is the most expensive form of dehydration, apart from freeze-drying, and the spray dried algae are not as digestible as drum dried material. (Kraut et al 1966, Pabst - 1975, Mohn - 1978).

\subsection{Other Heat-Drying Methods}

Cross-Flow Air Drying - The algae drying method was tested at CFRRI, Mysore, India. (Becker \& Venkataraman - 1982). The wet solids of Spirulina, containing 55 to $66 \%$ moisture, were dried at $62^{\circ} \mathrm{C}$ for 14 $\mathrm{h}$ in a compartment dryer. An approximately 2 to $3 \mathrm{~mm}$ thick algae layer gave a good dried product with $4-8 \%$ moisture. The process is cheaper than drum drying and more rapid than sun drying. In this method the cell wall of Chlorella and Schenedesmus can not be broken.

Vacuum She1f-Drying - Vacuum shelf-drying is another algae drying method which is reported by Becker \& Venkataraman - 1982. Spirulina was dryed in a vacuum shelf dryer at a temperature of 50 to $65^{\circ} \mathrm{C}$ and 0.06 at. pressure. The dried material had a residual moisture of $4 \%$. This method involves higher capital and running costs. The dryed product develops a hygroscopic property and porous structure.

Two other heat drying methods that differ somewhat from conventional heat drying systems are currently available. They are the 
Basic Extractive Sludge Treatment (BEST) process which employs solvent extraction, and the Carver Greenfield process which uses multipleeffect evaporation. Both of these systems employ an externally supplied liquid to assist in the removal of water from wet sludge. (EPA Marua: - 1979)

\subsection{Sun Drying}

Sun drying is one of the oldest methods for food preservation and is still used today especially in the developing countries. The sun drying process can be accomplished either by direct solar radiation or by hot circulated air which was sun heated previously, usually by collectors. In the first case the algae mass, either covered or uncovered, is exposed to direct solar radiation. The direct solar radiation causes chlorophil degradation in the algae mass, hence a preferred color for the final product is achieved. On the other hand, direct solar radiation can cause overheating of the materials, and in addition the method is strongly weather dependent. In the second case of indirect solar radiation, overheating of the algae mass is prevented and the drying rate is higher but the final product is less attractive and the cost is higher. This method is the more commonly used today.

Sun drying is not recommended for preparing an algae product intended for human consumption for two reasons. An unpleasant odor is associated with the slow sun drying process. In addition the algae mass must be subjected to a short duration of high heat $\left(120^{\circ} \mathrm{C}\right)$ in order to increase the giological value of the product and to be safe for human consumption.

For the production of animal feed, however, sun drying may be an acceptable solution (Richmond - 1983).

In Sde Boqer, Israel, fish feed made of Spirulina $20 \%$ dry matter, is mixed with a corn meal and dried in the sun. Dehydration is completed to $10 \%$ water within one day. The resultant product, Spirulina and corn meal mixture, is successfully used as the sole diet for Telapia fish in tanks. 
The feasibility of using a solar drier for drying Spirulina was tested in CFRI, India (Becker and Ventakaraman - 1982) as compared to direct sun drying. A solar dryer consisting of a wooden chamber with the inside surface painted black and the top covered $2 \mathrm{~mm}$ glass plate, developed. cemperature of $60-65^{\circ} \mathrm{C}$. A drying time of $5-6 \mathrm{~h}$ brought down the moisture in the dried product to about $4-8 \%$. An improved model with air circulation is under study. A more sophisticated. solar dryer using 3 layer PVC solar collectors was tested at CTRI Institute. Air temperatures as high as $70-75^{\circ} \mathrm{C}$ were recorded with a $30 \mathrm{~m}$ long collector on a clear day.

Simple models of solar dryers have also been developed at the A.M.M. Murugappa Chettiar Research Center, Madras for Spirulina (Technical dates - 1977, Seshadri et al - 1978). The sun drying was found to be relevant in the context of low level Technology that is being considered for India. Spirulina, used at the various trials at CFTRI is routinely and successfully sun dryed. The method is reported by Becker \& Venkataraman to be easy and inexpensive but weather dependent and involves a possible risk of fermentation and spilage, which can happen if the drying process lasts too long.

The effect of various drying methods on the digestibility of algae protein is shown in fig 5.1 (Payer et al - 1980).

Several other research projects in developing countries are investigating improved methods of small. scale solar drying of agricultural crops.

In Florida, the dissolved-air flotation float is solar dryed on a flat black cloth without prior dewatering. Partial dewatering is achieved by drainage through the supporting cloth. A plastic cover improves the drying rate. The area required for drying beds of this type was estimated to be equivalent to some $12 \%$ of high-rate pond area. (Lincoln \& Hall - 1980). 
Digestibility

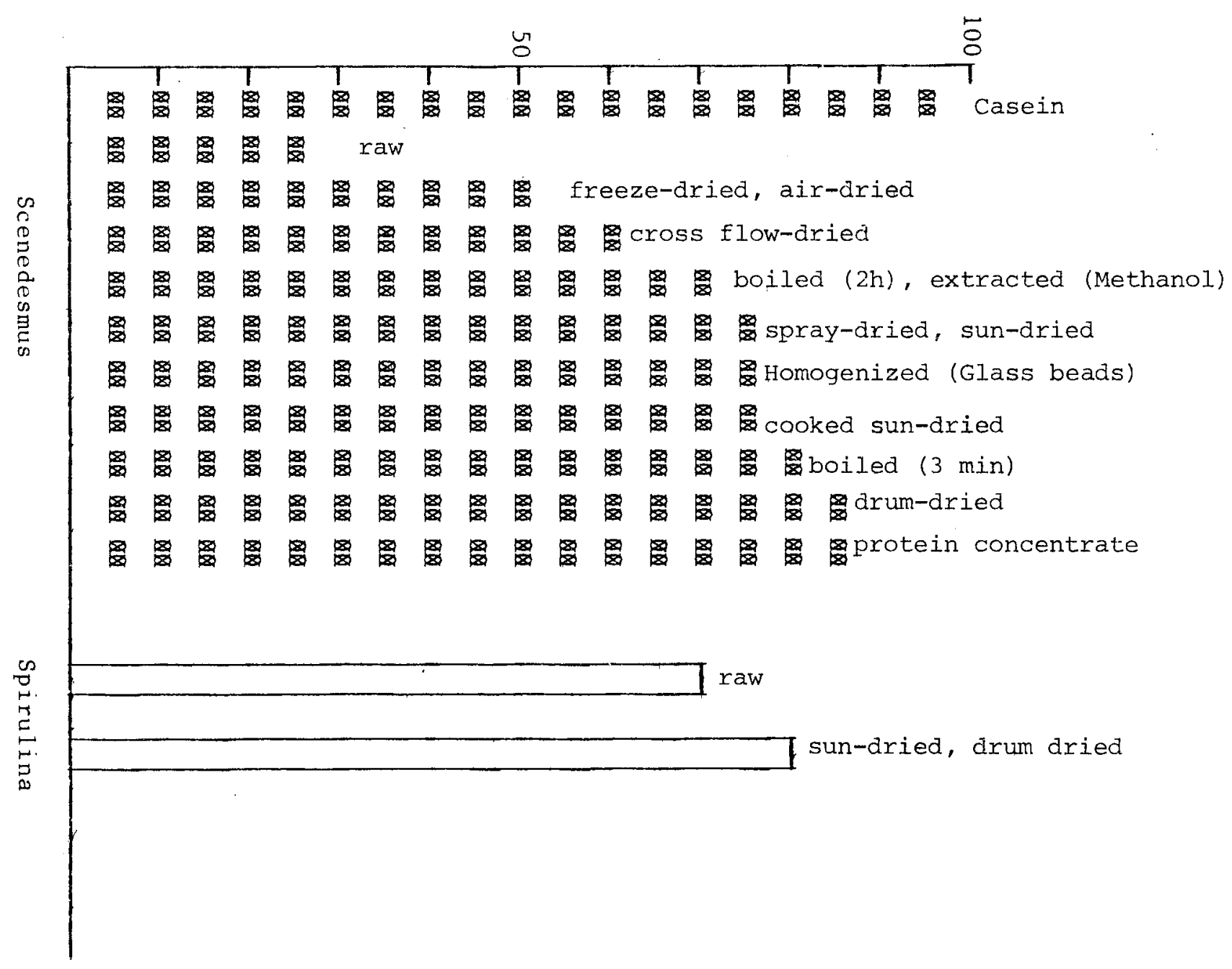


6. Summary, conclusions and recommendations

There is no unique answer to the question, which of the various methods and technologies of microalgae harvesting would be the most suitable. The decision of the preferable harvesting technology depends on $f \in w$ rariules: algae spicies, growth medium, algae production, end product and production cost benefit.

Algae size is an important factor since low-cost filtration procedures are presently applicable only for harvesting fairly large microalgae (e.g. Coelastrum, Spirulina). Small size microalgae should be flocculated into larger bodies which can be harvested by one of the above described methods. However cells mobility affects the flocculation process and addition of non residual exidants to stop the mobility should be considered as a flocculant aid.

The decision of either sedimentation or flotation methods, depends on the density difference between the algae cell and the growth medium. For oil laden algae with low cell density flotation tachnologies should be considered. Moreover, oxygen release from algae cells and oxygen supersaturation conditions in growth medium support the use of flotation methods.

Organic substances and other chemical compounds affect the flocculation optima. High salts content in culture medium (e.g. sea water) reduce the electric repulsion forces between the cells by the electric double layer compression, but at the same time reduce the effectivity of the added flocculant by streaming its functional groups.

If algae of high quality are to be produced (for human consumption), continuously harvesting by solid ejecting type or nozzle type disc centrifuges is recommended. These centrifuges can easily be cleaned and sterilized. They are suitable for all types of microalgae, but their considerable operational cost should be compared with the end product benefit. Chemical additives such as alum or other flocculants are concentrated in the algae slurry and restrict the use of the final product which is not suitable for human consumption. Moreover, animal feed on that prduct should be associated with toxicological studies. 
Airother basic citerion for selecting the suitable harvesting procedure is the final algae paste concentration which is required for the sequel process. Solid content of the paste greatly influences the drying expense and low water content is recommended. If chemical entraction $i$, inclibed in algae processing the requised slurry concentration should be assessed according to the extraction technology.

Solids requirements up to $30 \%$ can be attained by established dewatering process. For more concentrated solids, drying methods are required.

Vuder laboratory conditions no drying is necessary prior to lipids extraction for algae slurry. However, it is still unclear what is the optimal soids concentration requirement for the commercial process of lipids exiraction from algae.

In any wase the lrying stage is required for using the by-product, i.t., the algae slurty tollowing the lipids extraction.

The various systems for algae drying differ both in the extent of capital investment and in the energy requirements. Selection of the drying method depends on the scale of operation and also the use for wich the dried product is intended.

The removal of $1 \mathrm{~kg} . \mathrm{H}_{2} \mathrm{O}$ by drying requires more than $800 \mathrm{Kca} 1$ of energy, therefore any reduction of water content by dewatering techniques is beneficial from energetic and cost standpoints.

The final decision on the algae harvesting method should take in account all those parameters in choosing the right technology for the production system by cost benefit analysis.

Our literatire review on microalgae harvesting technologies does not reveal any revolutionary conceptual advances since the first comprehensive scudy done by Golueke and Oswald (1965). Nevertheless, optimizing various t.rains of processes can not only reduce the cost but can render the whole scheme to become economically feasible. The existing literature by itself is not conclusive enough to propose such optimal train of harvesting proceses and the continued work of the Technion Group in this project will try to establish such optimal train of processes. 
References

Adan B. \& Lee E.W. High rate algae growth pond under tropical conditions. Presented at a workshop on waste treatment and nutrient recovery. Singapore, 27-29 February 1980.

Arad S., Friedlander M., Ben Arie R. and Richmond A. Alkalinityinduced aggregation in Chlorella vulgaris. 1. Changes in cell volume and cell wall structure. Plant \& Cell Physiology. 21:27$35(1980)$.

Azov Y. \& Shelef G., Operation of high rate oxidation ponds: theory and experiments. Water Res. 16: 1153-1160 (1982).

Bare, W.F.R. Jones, N.B. and Middlebrooks E.J., Algae removal using dissolved air flotation. J. Water Poll. Control Fed. 47: 153-169 (1975).

Becker, W.E. (1978) Major results of the Indo-German algal project Arch. Hydrobiol. Beck., Ergebn. Lumnol. Vol. 1.

Becker, W.E., Venkataraman L.V., Khanun P.M. (1976), "Effect of different methods of processing on the protein efficiency ratio of the green algal Scenedesmus acutus", duration Report Int. 14(3), 1976.

Benemann J.R., Koopman, B.L., Baker, D., Weissman, J.C., Oswald, W.J. (1977) A systems analysis of bioconversion with microalgae, clean fuels from biomass and wasts, Inst. of Gas. Tech. Chicago, Ill. p. 101.

Benemann, J.R., liurry, M., Weissman, J.C. Hallenbeck, P.C. Oswa1d, W.J. (1977) Fertilizers production with Nitrogen fixing heteroystous blue-green algae - Final Report SERL, U.C. Berkeley, Rep. 78-3.

Benemann, J.R., Weissman, J.C., Eisenberg, D.M. Oswald, W.J., 1978, Large scale fresh water microalgae biomass production for fuel and fertilizer, Progress Rep. SERL. U.C. Berkeley.

Benemann, J.R., Weissman, J.C. Koopman, B.C. Hallenbeck, P.C., Eisenberg, D.M. Murry, M.A., Oswald, W.J. 1978 - Fuel from microalgal biomass. Proceedings 2nd Annual Symp. on Fuel from Biomass, Troy, N.Y. 
Benemann, J.R., Koopman, B.C. Weissman, J.R., Eisenberg, D.M. Goebel, R.P. 1980 - Development of microalgae harvesting and high rate pond technologies in California - from "Algal Biomass" by Shelef, G. \& Soeder, C.J. p. 457

Berry, A.E., 1961, "Removal of algae by microfilters" Jour. Amer. Water Works, Assn. 53, 1503 .

Betzer, N. Advanced treatment of oxidation ponds effluent by disinfection. M.Sc. thesis submitted to the Senate of the Technion, Israel Institute of Technology (1981), in Hebrew.

Bitton, G., Mitche11, R., 1974 "The removal of E. Coli bacteriophage $\mathrm{T}_{7}$ by magnetic filtration" Water Res. 8, p. 549

Bitton, G., Mitche11, R. De Latour, C., Maxwe11, E., 1974, "Phosphate Removal by magnetic filtration", Water, Res. 8, p. 107.

Bitton, G., Fox, J.L., Strickland, A.G. - 1974, Appl. Microbiol. 30(6), p. 905 .

Bodien, D.G. Steinberg, L.R. 1969, Microscreening effectively polishes activated sludge effluent" Water \& Waste Eng. 3, 9, 74.

Contreras, A highly efficient electrolytic method for microalgae flocculation from aqueous cultures. Biotech. Bioengineer. 23: $1165-1168$ (1981).

Conway, K. and Trainor, F.R., Scenedesmus morphology and flotation. J. Phyco1. 8: 138-143 (1972).

Cravens, J.B. Kormanick R.A. - "The upgrading of lagoons and wastewater treatment plants via microscreening" presented at the 51 st Ann. Meeting of the Central States WPCF Bloomington Minnesota.

Cravens, J.B. , Lauritch W.A. "Experiences in Iagoon algae removal and advanced secondary treatment with microscreens" Environ. Inc. Waukesha, Wisconsin.

Dodd, J.C., 1980. Harvesting algae grown on pig wastes in Singapore, Paper presented at a Workshop on High Rate Algae Ponds held in Singapore, 1980 .

Dodd, J.C. Anderson, J.L. 1977. An integrated high-rate pond-algae harvesting system, Prg. Wat. Tech. 9, 713. 
Diaper, E.W.J. 1969. "Tertiary treatment by microstraining", Water \& Sewage Works, 116, 202.

Eisenberg, D.M. Koopman, .B., Benemann J.R. and Oswald, W.J. Algal bioflocculation and energy conservation in microalgal sewage ponds. Biotech. Bioengineer. Symp. 11:429-448 (1981).

Fogg, G.E. Algal cultures and phytoplankton ecology. Univ. Wisconsin Press, (1975).

Folkman, Y., and Wachs, A.M. Removal of algae from stabiliztion pond effluent by lime treatment Water Res. 7:419-435 (1973).

Friedman, A.A., Peaks, D.A. \& Nichols, R.L. Algae separation from oxidation pond effluents. J. Water Po11. Contro1. Fed. 49: 111-119 (1977).

Funk, W.H. et al. Dissolved air flotation for harresting unicellular algae. Water \& Sew. Works 115:343 (1968).

Gaudin A.M., Davis N.S. and Bangs S.E. Flotation of Escherichia coli with sodium chloride. Biotech. Bioengineer. 4:211-222 (1962).

Golueke C.G., Oswald W.J. 1965. "Harvesting and Processing Sewage Grown Planktonic Algae", J.W.P.C.F. 37, 471.

Golueke C.G.., Oswald W.J. Surface properties and ion exchange in algae removal. J. Water Poll. Control Fed. 42:R304 (1970).

Goldman J.F. 1979. "Algae Proteins and the Human Diet", Water Res. 13 $(1,2), 1$.

Gregory J. Effect of polymers on colloid stability. Proc. of NATO Adv. Study Inst. on the Scientific Basis of Flocculation (1977).

Grieves R.B. \& Wang S. Foam separation of Escherichia coli with cationic surfactants. Biotech. Bioengineer 8:323-336 (1966).

Harris S.E., Felip D.S., Reynolds, J.H., Middlebrooks E.J. 1978. "Separation of Algae Cells from wastewater lagoon effluents. Vol I: Intermittent Sand Filtration to upgrade waste stabilization lagoon effluent", Report EPA 66/2-78-033 Utah Water Res. Lab. Logan.

Hegewald E. Untersuchungen zum Zetapotential von Planktonalgen. Arch. Hydrobiol. /Supp1. 42 (1) 14-90 (1972). 
Heussler P. "Advance and prospects of microalgae culture experiences of the Peruvian German microalgae project" in Proc. of the 2nd Egyptian Algae Sym. Edited by E1 Fouly M.M. March 1979 - Cairo. Hoyer U. \& Bernhardt H. Eliminirung organischer Substanzen aus Talsperrenwasser Durch Flockenfiltration., Wasser 55:33-46 (1980).

Hutchinson G.E. A Treatise on Limnology. John Wiley \& Sons Inc. (1967).

Ives K.J. The significance of surface electric charge on algae in water purification. J. Biochem. Microbiol. Tech. Engineer. 1:37-47 (1959).

Kogura K., Simidu U. \& Tagu N. Bacterial attachment to phytoplankton in seawater. J. Exp. Marine Biol., Ecol. 5:197-204 (1981).

Koopman B.L., Thomson R., Yackzan R., Benemann J.R., Oswald W.J. 1978. Investigation of the pond isolation process for microalgae separation from woodlands waste pond effluents. Final Report U.C. Berkeley.

Koopman, B.L. and Lincoln E.P. Autoflotation of algae from high rate pond effluent, Agricul. Wastes, 5:231-246 (1983).

Kormanik R.A., Cravens J.B. "Removal of algae by microscreening" Water \& Waste Eng. Nov. 1978.

Kumar H.D., Yadava P.K. \& Gaur J.P. Electrical flocculation of the unicellular green algae chlorella vulgaris. Aquatic Bot. 11:187195 (1981).

Laward T.T. "The Potential of Solar Agricultural dries in Developing Areas" from "Technology for Solar Energy Utilization" Development and Transfer Technology Series No. 5 N.Y. 1978.

Levin G.V., Clendenning J.R., Gibor A. and Bogar F.D. Harvesting of algae by froth flotation. Appl. Microbio1. 10:169 (1962).

Lewis R.F., Ebreth D.J. "Upgrading wastewater stabilization ponds to meet new discharge standards" Utah, Water Res. Lab. Logan P.71.

Marshall G.R., Middlebrooks E.J. 1973. Upgrading of wastewater lagoon effluent with incermittent sand filtration" Utah, Water Res. Lab. Utah State Univ. Logan.

McGarry M.G. Algae flocculation with aluminium sulphate and polyelectrolytes. J. Water. Poll. Control Fed. 42:R191 (1970) 
McGarry. M.G. \& Durrani S.M.A. Flotation as a method of harvesting algae from ponds. Research program report No. 5. Asian Institute of Technology, Bangkok (1970).

Middlebrooks E.J., Marshall G.R. 1974 in "Upgrading wastewater stabilization ponds to meet new discharge requirements" Logan, Utah, Utah Water Res. Lab., PRWF 159-1 p. 4/.

Middlebrooks E.J., Porcella D.B., Gearheart R.A., Marshall G.R., Reinold J.H., Grenney W.J. 1974. "Effects of temperature on oil refinery waste toxicity" J.W.P.C.K. 46(12) p. 2675.

Mohn H.F. 1978. Improved Technologies for Harvesting and Processing of Microalgae and their impact on production costs. Arch. Hydrobiol. Bech. Ergebn. Lemnol. Vol. 11 p. 228.

Mohn H.F. 1980. "Experiences and Strategies in the Recovery of Biomass from Mass Cultures of Microalgae: from "Algae Biomass" by Shelef G., and Solder C.J.

Moraine R., Shelef G., Sandbank E., Bar Moshe Z. \& Schwarbard L., Recovery of sewage born algae: Flocculation and centrifugation techniques. In Algae Biomass, G. Shelef \& C.J. Solder (eds) Elsevier/ North Holland (1980).

Narkis N. and Rebhun M. Inhibition of flocculation processes in systems containing organic matter. at Water Poll. Control Fed. Annual Conf., Detroit. Session 45 (1981).

Okamoto S., IEEE 1974. Trans Magnetics 10(3) p. 926.

Okudo T., Sugano I., Tsugi T. 1975. "Removal of Heavy Metals by Ferrite Copercipitation Technique" Presented at the IEEE Int. Conf. on Magnetics London, 1975.

O'Melia C.R. Coagulation in wastewater treatment. In the Scientific Basis of Flocculation. K.J. Ives (ed) (1978).

Oswald J.W., Golueke C.G. 1968. Harvesting and Processing of Waste Grown Microalgae In: D.F. Jackson, Algae, Man and the Environment. Syracuse Univ. Press p. 371.

Oswald W.J. The engineering aspects of microalgae. CRC Handbook of Microbiology Vol. 2. pp. 519-552 (1978). 
Paer1 H.W. \& Ustach J.F. Blue green algae scums: An explanation for their occurance during freshwater blooms. Limnol. \& Oceanogr. 27:212-217 (1982).

Pavoni J.L., Keiber S.W. and Boblitt G.T. The harvesting of algae as a food from wastewater using natural and induced flocculation techniques. in watewater us? in the production of lood and fiber - Proceeding pp. 435-496 (1974).

Payer H.D., Runke1 K.H. 1978. Env. pollutants in fresh water algae from open air mass cultures. Arch. Hydrobiol., Beih. Ergebn. Limno1.

Reinolds J.H., Harris S.E., Hil1 D., Felip D.S., Middlebrooks .EJ. 1974. Intermittent sand filtration to upgrade lagoons effluent. Preliminary report in "Upgrading Wastewater Stabilization Ponds to meet new Discharge Standards" by E.J. Middlebrooks et al. Utah Water Res. Lab. Logan.

Sandbank E., Shelef G. and Wachs A.M. Improved electroflotation for the removal of suspended solids from algae pond effluents. Water Res. 8:587-592 (1974).

Sandbank E. Harvesting of microalgae from wastewater stabilization pond effluents and their utilization as a fish feed. D. Sc. thesis presented to the senate of the Technion - Israel Institute of Technology (1979).

Schwartzburd L., Polyelectrolytes use for clarification of high rate oxidation pond effluents. M.Sc. thesis submitted to senate of the Technion - Israel Institute of Technology (1978).

Seshadri C.V., Thomas S. 1978. "Low Cost Clutivation and Processing of Algae Utilizing Solar Energy. Proc. National Solar Energy Convention, Bhavanagar. p. 41.

Shaw D:J., Electrophoresis. Academic Press (1969).

Shelef G., et al. Combined systems for algae wastewater treatment and reclamation and protein production. Technion Research and Development Foundation (1975-1981).

Shelef G., Azov Y., Moreine R. and Oron G. Algae mass production as an integral part of a wastewater treatment and reclamation system. In Algae Biomass, B. Shelef and C.J. Solder (eds) Elsevier/North Holl and (1980). 
Soeder, C.J., Massive clutivation of microalgae: Results and prospects. Hydrobiol. 72:197-209 (1980).

Stumm W. and O'Melia C.R. Stechiometry of coagulation. Jour. AWWA $60: 514$ (1968).

Stumm W. and Morgan J.J. Aquatic chemistry. Wiley Interscience (1981).

Sukenik A. and Shelef G. Algae autoflocculation - verification and proposed mechanism. Biotech. Bioengineer - in press.

Svarovsky L. 1979. "Solids Liquids Separation" Chemical Eng. July 2 p. 63.

Svarovsky L. Advanced in solid-liquid separation II sedimentation, centrifugation and flotation. Chemical Engineering July 16. Pp. 43-105 (1979b).

Tenny M.W., Echelberger W.F. Jr., Schuessler R.G. and Pavoni J.L., Algae flocculation with synthetic organic polyelectrolytes. Appl. Microb. 18:965-971 (1969).

Tilton R.C. and Murphy J., The flocculation of algae with synthetic polymeric flocculants. Water Res. 6:155-164 (1972).

Van Vuuren L.R.J. et al 1960. Reclamation of purified sewage effluent for augementation of domestic water supply of Windholk, S. Africa. Final Report, CSJR Contract Report to $C$ Wat 4.

Van Vuuren L.R.J., Meiring P.G.J., Henzen M.R. and Koble F.F. The flotation of algae in water reclamation. Int. J. Air Water Poll. $9: 823-832$ (1965).

Van Vuuren L.R.J. and Van Duuren F.A. Removal of algae from waste water maturation pond effluent. J. Water Poll. Control Fed. $37: 1256$. (1965).

Venkataraman L.V. 1980 "Algae as food/feed" Proc. dat. work. Algae Systems. India Society of Biotechnology. HT India p. 83. 
Venkataraman L.V., Nigam B.P. and Ramanathan P.K. Rural oriented fresh water cultivation and production of algae in India. In Algae Biomass, G. Shelef and C.J. Solder (eds) Elsevier/North Holland (1980).

Viviers J.M.P. and Briers J.S. Harvesting of algae grown on sewage. Water SA 8:178-186 (1982).

Williams J.R. 1974. "Solar Energy Technology and Applications" Ann Arbor Science.

Wettman J.W., Cravens J.B. 1980. "Cost Effective Lagoon Upgrading with Microscreens" Presented at the 3rd Ann. Pol1. Cont. Assoc. Oklahoma Conference June 5, 1980.

Yadida R., Abeliovich A., Belfort G. Algae removal by high gradient magnetic filtration. Env. Sci. \& Tech. 11:913-916.

Yang L.B., Wing L.K., McGarry M.G. and Grahan M. Overview of wastewater treatment and resource recovery. Report on the workshop on high rate algae ponds. Singapore 22-27 February 1980 .

Annual Reports of A11 India Coordinated Projection Algae 1976-81. Sponsored by Dep. of Science \& Technology, India.

Technical notes 1977. Shri A.M.M. Murugappa Chettiar Research Center, Tharamani, Madras, India.

Brace Research Inst. "A Survey of Solar Agricultural Driers" Tech. Report T 99, McGi11 Univ. Canada 1975.

Production and Utilization of Microalgae - A Brief Survey - in Proc. of the 2nd Egyptian Algae Sym. Edited by E1-Fouly M.M. March 1979, Cairo. 


\begin{tabular}{|c|c|c|}
\hline $\begin{array}{l}\text { Document Control } \\
\text { Page }\end{array}$ & \begin{tabular}{|l|l|} 
1. SERI Report No. & 2. NTIS Accession No. \\
SERI/STR-231-2396 &
\end{tabular} & 3. Recipient's Accession No. \\
\hline \multirow{3}{*}{\multicolumn{2}{|c|}{$\begin{array}{l}\text { 4. Title and Subtitle } \\
\text { Microalgae Harvesting and Processing: A } \\
\text { Literature Review }\end{array}$}} & \multirow{2}{*}{$\begin{array}{r}\text { 5. Publication Date } \\
\text { August } 1984 \\
\end{array}$} \\
\hline & & \\
\hline & & 6. \\
\hline \multicolumn{2}{|c|}{ 7. Author(s) } & 8. Performing Organization Rept. No. \\
\hline \multirow{2}{*}{\multicolumn{2}{|c|}{$\begin{array}{l}\text { 9. Performing Organization Name and Address } \\
\text { Technion Research and Development Foundation Ltd. } \\
\text { Haifa, Israel }\end{array}$}} & $\begin{array}{c}\text { 10. Project/Task/Work Unit No. } \\
4625.10\end{array}$ \\
\hline & & $\begin{array}{l}\text { 11. Contract (C) or Grant (G) No. } \\
\text { (C) } \\
\text { (G) }\end{array}$ \\
\hline \multirow{3}{*}{\multicolumn{2}{|c|}{$\begin{array}{l}\text { 12. Sponsoring Organization Name and Address } \\
\text { Solar Energy Research Institute } \\
1617 \text { Cole Boulevard } \\
\text { Golden, Colorado } 80401\end{array}$}} & \multirow{2}{*}{$\begin{array}{l}\text { 13. Type of Report \& Period Covered } \\
\text { Technical Report }\end{array}$} \\
\hline & & \\
\hline & & 14. \\
\hline \multicolumn{3}{|c|}{$\begin{array}{l}\text { 15. Supplementary Notes } \\
\text { Technical Monitor: Robins McIntosh }\end{array}$} \\
\hline \multicolumn{3}{|c|}{$\begin{array}{l}\text { 16. Abstract (Limit: } 200 \text { words) } \\
\text { Analyzing the existing } 1 \text { iterature is not sufficient at this stage to determine } \\
\text { the optimal train of processes to accomplish an economically feasible microalgae } \\
\text { scheme as a source of energy, chemicals and other uses. It nevertheless pro- } \\
\text { vides the baseline for the continuing work aimed to accomplish such optimization } \\
\text { which is of crucial importance to any practical and economical microalgae scheme. } \\
\text { There is no unique answer to the question which of the various methods and } \\
\text { technologies of microalgae harvesting would be the most suitable. The decision } \\
\text { of the preferable harvesting technology depends on few variables: algae species, } \\
\text { growth medium, algae production, end product and production cost benefit. Our } \\
\text { literature review on microalgae harvesting technologies does not reveal any } \\
\text { revolutionary conceptual advances since the first comprehensive study done by } \\
\text { Golueke and Cswald (1965). Nevertheless, optimizing various trains of processes } \\
\text { can not only reduce the cost, but can render the whole scheme economically } \\
\text { feasible. }\end{array}$} \\
\hline \multirow{2}{*}{\multicolumn{3}{|c|}{$\begin{array}{l}\text { 17. Document Analysis } \\
\text { a. Descriptors ATgae; Drying; Filtration; Flocculation; Flotation; Harvesting; } \\
\text { Screens; Sedimentation; Separation Processes; Suspensions } \\
\text { b. Identifiers/Open-Ended Terms }\end{array}$}} \\
\hline & & \\
\hline \multicolumn{3}{|l|}{ c. UC Categories } \\
\hline \multicolumn{3}{|l|}{$61 \mathrm{a}$} \\
\hline \multirow{2}{*}{\multicolumn{2}{|c|}{$\begin{array}{l}\text { 18. Availability Statement } \\
\text { National Technical Information Service } \\
\text { U.S. Department of Commerce } \\
5285 \text { Port Royal Road } \\
\text { Springfield, Virginia } 22161\end{array}$}} & $\begin{array}{r}\text { 19. No. of Pages } \\
70\end{array}$ \\
\hline & & $\begin{array}{r}\text { 20. Price } \\
\\
\mathrm{AO} 04\end{array}$ \\
\hline
\end{tabular}

